\title{
CHARACTERIZATION OF PSEUDOMONAS SYRINGAE PV. SYRINGAE FROM DISEASED STONE FRUITS IN KYRGYZSTAN AND TESTING OF BIOLOGICAL AGENTS AGAINST PATHOGEN
}

Tinatin Doolotkeldieva, Saikal Bobushova

Plant Protection Department, Faculty of Agriculture, Kyrgyz-Turkish Manas University, Bishkek city, 720044, Kyrgyzstan.

\section{A R T I C L E I N F O}

\section{Article history}

Received: May 08, 2020

Revised: July 07, 2020

Accepted: August 18, 2020

\section{Keywords}

Stone fruits

Bacterial canker

Pseudomonas syringae pv.

syringae

Bio control agent

Streptomyces bacteria
A B S T R A C T

The plant diseases caused by the Pseudomonas syringae complex bacteria are economically important and occur worldwide on various plants, and it is as a pathogen that has not been the object of studies and little is known about its epidemiology in Kyrgyzstan. The conventional phenotypic (LOPAT, API tests) and PCR-assisted isolation were used for the identification of Pseudomonas syringae pv. syringae isolates from the affected organs of local stone fruits, such as peach (Prunus persica), cherry (Prunus subgen), apricot (Prunus armeniaca), and plum (Prunus salicina) samples taken from the Chy, Issuk-Kul, and Batken regions of the country. 16S rRNA gene amplification was performed with primers 27F (5'-AGA GTT TGA TCC TGG CTC AG -3') and 907R (5 '-CCG TCA ATT CCT TTG AGT TT-3') for the identification of obtained P.syringae pv. syringae isolates. From 40 primary isolates of Gram-negative rod-shaped bacteria, 12 were identified as Pseudomonas syringae $p v$. syringae, while the remaining isolates were identified as bacteria from Stenotrophomonas, Xanthomonas, Erwinia genera. The antagonist bio control agentStreptomyces bacteria strains were screened and selected against the bacterial canker pathogen in in vitro experiments and on apricot seedlings in vivo conditions. Obtained results could encourage to develop a local bio-product based on this bioagent for spraying stone fruits with the initial manifestation of disease symptoms and to conduct preventive treatments in the fall and spring to increase the plant's resistance to pathogens.

Corresponding Author: Tinatin Doolotkeldieva

Email: tdoolotkeldieva@gmail.com

(C) The Author(s) 2020.

\section{INTRODUCTION}

The plant diseases caused by the Pseudomonas syringae complex bacteria are economically important and occur worldwide on various plants. Among plant pathogenic bacteria, Pseudomonas, pv. syringae can cause diseases in more than 180 plant species including annual and perennial plants, fruit trees, ornamentals, and vegetables (Little et al., 1998; Agrios, 2005; Lamichhane et al., 2014; Lamichhane et al., 2015). The phytopatogenic pseudomonads cause plant diseases with different symptoms, including cankers, diebacks, blossom, twig, leaf or kernel blights, leaf spots $(P$. syringae different pathovars), soft and brown rots ( $P$. viridiflava, $P$. marginalis different pathovars), tumors or galls ( $P$. savastanoi pathovars), mushroom blights ( $P$. tolasii, $P$. agarici pathovars), and tomato ( $P$. syringae pv. tomato) (Koike et al., 2017; Braun-Kiewnick and Sands, 2001; Choi et al., 2016; Ahmed et al., 2018).

Meanwhile, other authors noted that $P$. syringae strains form an overlapping continuum of host range potential with equal representation of narrow, moderate, and broad host ranges (Morris et al., 2019). Several examples 
have been observed for the overlapping of this pathogen bacteria, in that sugar beet and cucurbits are considered as common hosts for $P$. syringae strains (Morris et al., 2000; Sedighian et al., 2014). P. syringae pv. garcae is not a coffee pathogen but can affect coffee seedling (Destéfano et al., 2010). P. syringae pv. lachrymans is a pathogen of the ornamental tree White Bird of Paradise (Strelitzia augusta), which has shown a virulence on zucchini (Polizzi et al., 2005).

$P$. syringae bacteria as the ubiquitous pathogen of numerous plant species has a special name-P. syringae sensu lato-proposed by (Morris et al., 2013). This group consists of a phylogenetic line containing related species P. syringae (Mulet et al., 2010). The multilocus sequence analysis (MLSA) (Berge et al., 2014) allowed to classify the metapopulation of $P$. syringae strains involved in various agricultural plant diseases (Lamichhane et al., 2014; Lamichhane et al., 2015). P. syringae is composed of plant pathogens divided into 60 pathovars (Young, 210) belonging to nine genomospecies, as determined by DNA: DNA hybridization (Gardan et al., 1999).

The diagnostics of bacterial canker are commonly based on isolation and the phenotypic characterization of the causal agent, including pathogenicity (Bultreys and Gheysen, 1999; Vicente et al., 2004). The phenotypic tests LOPAT (Lelliott et al., 1966; Lelliott and Stead, 1987), GATTa ,and L-lactate utilizations (Latorre and Jones, 1979) enable the determination of morphological, physiological, and biochemical characteristics of the bacteria. On King's B medium, the majority of these bacteria produce a fluorescent pigment visible under UV light (King et al., 1954).These tests are used for the identification of species and their discrimination into pathovars and races.

To protect plants from diseases caused by $P$. syringae pathogen, such bio-control bacteria like $P$. aeruginosa strain D4, Bacillus stratosphericus strain FW3, Paenibacillus polymyxa AC -1 were screened in vitro and in vivo trials. Pseudomonas aeruginosa strain D4 and Bacillus stratosphericus strain FW3 isolated from mine tailings in South Korea have shown improved antagonistic activity against $P$. syringae DC3000. The biocontrol efficiency of the potential strains on the $S$. lycopersicum plant against $P$. syringae pathogen was resulting in growth promotion and in vivo antagonistic activity (Durairaj et al., 2018).

The biocontrol ability of a wild-type $B$. subtilis strain 6051 against the bacterial pathogen $P$. syringae pv. tomato DC3000 infecting Arabidopsis roots was evaluated in vitro and in soil. The minimum inhibitory concentrations of $B$. subtilis were relatively high $(25 \mathrm{mg}$ $\mathrm{mL}^{-1}$ ) to be sufficient to kill $P$. syringae (Bais et al., 2003). Paenibacillus polymyxa AC-1 rhizobacterium has been examined for effects on bacterial phytopathogen $P$. syringae and this biocontrol agent has inhibited the growth of both $P$. syringae pv. tomato and $P$. syringae pv. tabaci in a concentration-dependent manner in vitro assays (Hong et al., 2016). P. fluorescens biocontrol bacteria isolated from flowers of Actinidia deliciosa and $A$. chinensis were tested against $P$. syringae pv. actinidiae (Psa), the causal agent of kiwifruit bacterial canker and were able to inhibit Psa growth in vitro and to reduce disease incidence in planta (Donati et al., 2018).

Bacterial canker is the most harmful disease of the cultivated varieties of apricots, plums, cherries, peaches, and ornamental Prunus species in Kyrgyzstan. It causes sunken patches of dead bark and small holes in leaves, called "shothole". P. syringae pv. syringae is a pathogen that has not been the object of studies and little is known about its epidemiology in Kyrgyzstan. Additional problem is a limited number of measures are available to control bacterial plant diseases. A better understanding of the disease epidemiology would help limit its incidence by providing more information on the correct timing for the application of protective sprays.

This study aimed to isolate, identify, and screen the $P$. syringae group bacteria using the widely used and still highly sensitive culture approach, and by the PCR analysis of $16 \mathrm{~S}$ rRNA gene for the identification of obtained natural isolates of $P$. syringae and select and develop biocontrol agents for the protection of stone fruit orchards from bacterial canker.

\section{METHODS AND MATERIAL \\ Plant Sample Collection}

In spring 2015-2017, early summer, and autumn expeditions were organized to different stone fruit growing regions of the country. The samples were taken from different varieties of apricot (Prunus armeniaca), peach (Prunus persica), plum (Prunus salicina), and cherry (Prunus subgen) with disease symptoms in Chy, Batken, and Issyk-Kul valleys to isolate the bacterial canker pathogen isolates. An additional one hundred samples (leaves, stems, spurs, and bark with gummy ooze) from 14 orchards were collected (Table 1). 
Table 1. Samples taken from diseased plants.

\begin{tabular}{|c|c|c|c|}
\hline Time of sampling & Sampling place, GPS coordinates & Plant species & Plant organs \\
\hline $\begin{array}{l}\text { The end of April and May } \\
2015 \text {, and October } 2015 \\
\text { and } 2017\end{array}$ & $\begin{array}{l}\text { Botanical Garden named after } \\
\text { Gareev, Bishkek city } \\
42^{\circ} 52^{\prime} 12^{\prime \prime} \mathrm{N} 74^{\circ} 35^{\prime} 24^{\prime \prime} \mathrm{E}\end{array}$ & $\begin{array}{l}\text { Different varieties of apricots, } \\
\text { plums, and peaches }\end{array}$ & $\begin{array}{l}\text { The affected } \\
\text { shoots, leaves, } \\
\text { barks ,and fruits }\end{array}$ \\
\hline $\begin{array}{l}\text { May 2015, and October } \\
2015,2016 \text {, and } 2017\end{array}$ & $\begin{array}{l}\text { Bishkek city } \\
42^{\circ} 52^{\prime} 12^{\prime \prime} \mathrm{N} 74^{\circ} 35^{\prime} 24^{\prime \prime} \mathrm{E}\end{array}$ & $\begin{array}{l}\text { Different varieties of apricots } \\
\text { and plums, cherries }\end{array}$ & $\begin{array}{l}\text { The affected } \\
\text { shoots and leaves }\end{array}$ \\
\hline $\begin{array}{l}\text { The end of April and May } \\
\text { 2015, and October 2015, } \\
2016 \text {, and } 2017\end{array}$ & $\begin{array}{l}\text { Chui region, Vorontsovka, Kokzhar } \\
\text { villages } \\
42^{\circ} 49^{\prime} 11^{\prime \prime} \text { N 75¹6'56.4" E }\end{array}$ & $\begin{array}{l}\text { Different varieties of apricots, } \\
\text { peaches, and plums, cherries }\end{array}$ & $\begin{array}{l}\text { The affected } \\
\text { shoots, leaves, } \\
\text { barks, and fruits }\end{array}$ \\
\hline $\begin{array}{l}\text { October 2015, 2016, and } \\
2017\end{array}$ & $\begin{array}{l}\text { Chui region, Ak-Beshim wild } \\
\text { apricot orchard } \\
42^{\circ} 53^{\prime} 4.3^{\prime \prime} \mathrm{N} 74^{\circ} 40^{\prime} 41.5^{\prime \prime} \mathrm{E}\end{array}$ & $\begin{array}{l}\text { Wild varieties of apricots, } \\
\text { cherries }\end{array}$ & $\begin{array}{l}\text { The affected } \\
\text { shoots and leaves }\end{array}$ \\
\hline $\begin{array}{l}\text { October 2016, and May } \\
2017\end{array}$ & $\begin{array}{l}\text { Issyk-Kul region, Fruit farming of } \\
\text { Balykchy, Bokonbaevo villages } \\
42^{\circ} 7^{\prime} 3.7^{\prime \prime} \mathrm{N} 76^{\circ} 59^{\prime} 35.9^{\prime \prime} \mathrm{E} \\
42^{\circ} 27^{\prime} 44.9^{\prime \prime} \mathrm{N} 76^{\circ} 11^{\prime} 23.9^{\prime \prime} \mathrm{E}\end{array}$ & Different varieties of apricots & $\begin{array}{l}\text { The affected } \\
\text { shoots, leaves, } \\
\text { and barks }\end{array}$ \\
\hline $\begin{array}{l}\text { October } 2016 \text { and May } \\
2017\end{array}$ & $\begin{array}{l}\text { Issyk-Kul region, fruit farming of } \\
\text { Tosor, Zharkynbaevo, Khajisai, and } \\
\text { Zhargylchak villages } \\
42^{\circ} 9^{\prime} 56.5^{\prime \prime} \mathrm{N} 77^{\circ} 26^{\prime} 39.8^{\prime \prime} \mathrm{E} \\
42^{\circ} 8^{\prime} 17.5^{\prime \prime} \mathrm{N} 77^{\circ} 10^{\prime} 38.2^{\prime \prime} \mathrm{E}\end{array}$ & Different varieties of apricots & $\begin{array}{l}\text { The affected } \\
\text { shoots , leaves, } \\
\text { barks, and fruits }\end{array}$ \\
\hline October 2016 & $\begin{array}{l}\text { Batken region, Apricot farming } \\
\text { villages } \\
39^{\circ} 46^{\prime} 6.6^{\prime \prime} \mathrm{N} 69^{\circ} 27^{\prime} 50.3^{\prime \prime} \mathrm{E}\end{array}$ & Different varieties of apricots & $\begin{array}{l}\text { The affected } \\
\text { shoots leaves, } \\
\text { and fruits }\end{array}$ \\
\hline
\end{tabular}

\section{Extraction of bacteria from primary materials}

Samples were washed and cut in pieces in a sterile bag, then placed in a suitable container such as a disposable $150 \mathrm{ml}$ plastic cup with lid or a $200 \mathrm{ml}$ Erlenmeyer flask. Furthermore, $30 \mathrm{ml}$ phosphate-buffered saline was added. Subsequently, the container was placed on a rotary shaker and incubated at $200 \mathrm{rev} / \mathrm{min}$ for $1 \mathrm{~h}$. For samples with symptoms, an appropriate amount of macerate was selected for the polymerase chain reaction (PCR) analysis. As regards asymptomatic samples, extracted suspension was concentrated by centrifugation, and $50 \mathrm{ml}$ of macerate was carefully poured either directly into the centrifuge tube-leaving the pulp in a container-or prefiltered through filter paper and then centrifuged for 10 minutes, with an acceleration of $8000 \mathrm{~g}$. The sample was also frozen at $-18^{\circ} \mathrm{C}$.

The supernatant was discarded without damage; the pellet was resuspended in $1 \mathrm{ml}$ of phosphate buffer and transferred to a sterile microtube. The extract was then used immediately for the selection tests: biochemical and PCR analyses (Bultreys and Gheysen, 1999; BraunKiewnick and Sands, 2001; Stefani and Loreti, 2014).
Mediums for isolation and characterization of Pseudomonas syringae bacteria

Differential and semi-selective mediums were used for the characterization of colonies based on the color, texture, and other cultural features.

Pseudomonas Isolation Agar (Millipore, Sigma-Aldrich) consists of: agar, $11.6 \mathrm{~g} / \mathrm{L}$; magnesium chloride $6 \mathrm{H}_{2} \mathrm{O}$, $1.4 \mathrm{~g} / \mathrm{L}$; peptic digest of animal tissue, $16.0 \mathrm{~g} / \mathrm{L}$; casein enzymic hyrolysate, $10.0 \mathrm{~g} / \mathrm{L}$. This medium was used for primary isolation and identification of Pseudomonas bacteria from plant samples.

King Agar B medium (Millipore, Sigma-Aldrich) consists of: peptone $5 \mathrm{~g}$; glycerol $10 \mathrm{ml} ; \mathrm{K}_{2} \mathrm{HPO}_{4}, 1.5 \mathrm{~g}$; $\mathrm{MgSO}_{4} .7 \mathrm{H}_{2} \mathrm{O}-1.5 \mathrm{~g}$; agar $20 \mathrm{~g}$; distilled water $1 \mathrm{~L}$; $\mathrm{pH}$ 7.07.2; sterilized by autoclaving at $120{ }^{\circ} \mathrm{C}$ for $20 \mathrm{~min}$. This medium was used for density growth, fluorescing and producing yellow-green pigment colonies.

Levan medium (Millipore, Sigma-Aldrich) consists of: yeast extract- $5 \mathrm{~g}$; bactopeptone- $5 \mathrm{~g}$; $\mathrm{NaCl}, 5 \mathrm{~g}$; sucrose 50 g; agar $20 \mathrm{~g}$; distilled water $1 \mathrm{~L}$; $\mathrm{pH}$ 7.0-7.2; sterilized by autoclaving at $120{ }^{\circ} \mathrm{C}$ for $20 \mathrm{~min}$. This medium was used for levan or a polyfructan production by $P$. syringae. 
Glucose Peptone Agar (Millipore, Sigma-Aldrich) consists of: peptic digest of animal tissue $20.0 \mathrm{~g} / \mathrm{L}$, dextrose $10.0 \mathrm{~g} / \mathrm{L}$; sodium chloride $5.0 \mathrm{~g} / \mathrm{L}$; agar 15.0 $\mathrm{g} / \mathrm{L}$, final $\mathrm{pH}$ (at $25{ }^{\circ} \mathrm{C}$ ) $7.2 \pm 0.2$. This highly nutritious medium was used to support the growth of fastidious microorganisms, like $P$. syringae and for general cultivation.

Nutrient agar (Millipore, Sigma-Aldrich). Ingredients (g/L): Peptic digest of animal tissue $5.0 \mathrm{~g}$ Beef extract $3.0 \mathrm{~g}$, Agar $15.0 \mathrm{~g}$. This composition was used for the cultivation of isolated bacteria.

\section{Isolation of the pure culture of Pseudomonas syringae}

In order to isolate the P. syringae isolates from prepared primary materials as well as identify and store them in vitro, the selective mediums such as Pseudomonas Isolation Agar; King's B medium (King et al., 1954), Levan, Glucose peptone agar (GPA) and nutrient agar (NA) with sucrose were used. A 30-50 $\mu$ dose of plant extract suspension from the diseased parts was added to the Petri dish and sequentially distributed over the surface of the King's B medium on three plates with a spatula. The stroke method was also used for plating the plant extract suspension on Pseudomonas Isolation Agar. For this purpose, four decimal dilutions of plant extract were prepared in the extraction buffer followed by 50$100 \mu \mathrm{l}$ of undiluted extract, before each dilution was plated on its medium with the stroke method. In order to control the quality of the medium, the reference strains of bacterial canker pathogen were plated. After $28 \mathrm{~h}$ of incubation at $28{ }^{\circ} \mathrm{C}$, Pseudomonas such as colonies were purified twice on King's B medium before being characterized. All the strains were maintained in King's B medium at $4{ }^{\circ} \mathrm{C}$ for collection and other biochemical tests.

\section{The classical biochemical tests}

Biochemical tests were set for the study of phenotypic properties of the $P$. syringae isolates based on LOPAT (levan production, oxidase test, potato rot, arginine dihydrolase, and tobacco hypersensitive reaction) and GATTa's (gelatin liquefaction, aesculin hydrolysis, tyrosinase activity, and Na-tartrate utilization) group tests (Lelliott et al., 1966; Lelliott and Stead, 1987).

\section{The hypersensitivity of plant tissue to Ps. syringae}

In vitro bioassay tests to identify the hypersensitivity of non-specific plant organisms to isolated bacterial canker pathogens were performed. Tobacco plants (Nicotiana tabacum var Hicks) were grown in a greenhouse for eight to 12 weeks after transplanting. Fully expanded upper leaves were inoculated by injecting bacterial suspensions of $1 \times 10^{8}$ viable bacteria/ml into the intercellular spaces. The cells were washed using $3.4 \mathrm{ml}$ of saline and 15-20 $\mu \mathrm{l}$ was injected into the pulp of leaves with a sterile syringe. As a control, the same volume of sterile physiological saline was injected (Johansson et al., 2015).

Artificial infection of pear, cherry, and plum fruits to determine the Ps. syringae virulence

The most common and simple White method was used for the identification of the degree or strength of the virulence of the locally obtained isolates. In these tests, the immature and mature pear, cherry, and plum fruits were inoculated with $P$. syringae liquid culture $\left(10^{9}\right.$ of cells $/ \mathrm{ml}$ ), and the fruits were kept in a humid chamber. In control, the fruits were inoculated with sterile water. The results were estimated by a 5 -point scale.

\section{Temperature effects on the in vitro growth of Ps. syringae isolates}

The Ps. syringae isolates were cultivated in peptone meat broth on the shaker (200 rev/min) at the different temperatures of $15,20,28$, and $40{ }^{\circ} \mathrm{C}$ for 48 hours of incubation. The optical density of bacterial suspension was measured at $525 \mathrm{~nm}$ (Janyway, UK) and a standard curve was created. The number of bacteria was subsequently counted.

\section{Assessment of the antibiotic impact on the Ps. syringae isolates}

During this experiment, YGA and YPA mediums were used. The molten medium was mixed with the bacterial culture and poured into Petri dishes. After cooling, the wells of $10 \mathrm{~mm}$ in diameter were made in the medium. These wells were filled with antibiotic solutions (erythromycin, ofloxacin, penicillin, and tetracycline) of $50 \mathrm{mg} / \mathrm{ml}, 100 \mathrm{mg} / \mathrm{ml}, 150 \mathrm{mg} / \mathrm{ml}$, and $200 \mathrm{mg} / \mathrm{ml}$ doses respectively, and incubated at $28{ }^{\circ} \mathrm{C}$ for $48 \mathrm{~h}$. The appearance of lysis zones around the wells proved the sensitivity of pathogen cultures to various antibiotics.

In vitro determination of antibiotic activity of antagonistic microorganisms against the pathogen The agar blocks method was used. Biocontrol 
antagonistic microorganisms (Streptomyces sp.) were plated onto the surface of the agar medium in a Petri dish, having formed during the growth of a continuous lawn. Cultures were incubated at a suitable temperature for four to five days. Then a sterile cork drill (6-8 $\mathrm{mm}$ in diameter) was used to cut from the layer agar blocks and transferred to the surface of the agar medium, inoculating only the test organism ( $P$. syringae). The appearance of lysis zones around the wells has proved the sensitivity of pathogen cultures to Streptomyces biocontrol strains. Total of six Streptomyces strains were tested against $P$. syringae isolates; the tested experiments were performed in triplicate.

Screening the antibiotic activity of antagonistic microorganisms against the bacterial canker pathogen on apricot seedlings

The potential of candidate antagonists to suppress the cell production of $P$. syringae on infected leaves was tested on susceptible local apricot seedlings. Seedlings were sprayed with suspensions of $P$. syringae $\left(1 \times 10^{6} \mathrm{ml}^{-1}\right)$ until runoff and seedlings were incubated for five days at $85 \%$ $\mathrm{RH}, 15{ }^{\circ} \mathrm{C}$ and with $16 \mathrm{~h}$. of light per day. Thereafter, $P$. syringae inoculated seedlings were sprayed with antagonist suspensions (containing $1 \times 10^{6}$ spores or cells $\mathrm{ml}^{-1}$ ) or water (containing $0.01 \%$ Tween 80 ) as controls. Two seedlings of both apricots were used for each replicate of each treatment. Contact between leaves of neighbouring plants was avoided. Seedlings were grown for 9 to 12 days at $15{ }^{\circ} \mathrm{C}$, with $16 \mathrm{~h}$ of light per day at 138 $\mu \mathrm{E} \mathrm{s}^{-1} \mathrm{~m}^{-2}$. From both seedlings of each replicate, the youngest five true leaves were carefully removed, put into Duran bottles $(100 \mathrm{ml})$ containing $35 \mathrm{ml}$ of tap water with $0.01 \%$ Tween 80 . Four, 10, 15 and 20 days after treatment with antagonist cultures, five leaves of the apricot seedling were removed for microscopy and planting on the relevant mediums.

\section{Molecular Identification}

Sample preparation for polymerase chain reaction

King's B medium-positive, fluorescent culture at a concentration of $10^{6} \mathrm{cells} / \mathrm{ml}$ in sterile distilled water suspension was prepared and used immediately or stored at $-18{ }^{\circ} \mathrm{C}$ until the PCR product was observed.

\section{Polymerase chain reaction}

Total DNA was isolated with a cell using DNeasy Blood Tissue Kit according to standard protocols of QIAGEN,
Germany. Amplification was performed with a Multigene Thermal Cycler (TC9600-G/TC, Labnet International), using a $25 \mu \mathrm{l}$ mixture containing $15 \mu \mathrm{l}$ of PCR Master Mix (Taq DNA polymerase, $\mathrm{MgCl}_{2}$, deoxy-ribonucleotide triphosphate and reaction buffer), $2 \mu \mathrm{l}$ of each primer, $1 \mu \mathrm{l}$ of template DNA, and $1 \mu \mathrm{l}$ of $\mathrm{H}_{2} \mathrm{O}$. The amplification program was used as follows: $95^{\circ} \mathrm{C}$ for $5 \mathrm{~min}$, followed by 30 cycles of 1 minute denaturation at $95{ }^{\circ} \mathrm{C}, 1$ minute annealing at $55^{\circ} \mathrm{C}, 1$ minute extension at $72{ }^{\circ} \mathrm{C}$, and a final extension step of 5 minutes at $72{ }^{\circ} \mathrm{C}$. The PCR products were electrophoresed in a $2.0 \%$ agarose gel and visualized using the BioDoc-It ${ }^{\mathrm{TM}}$ Imaging Systems (UltraViolet Products Ltd.) after ethidium bromide staining. In order to control contamination, we used a negative control reaction and sterile water was added as a matrix.

\section{Statistical analysis}

In order to determine the difference between the disease index in plants and the inoculation methods (direct versus indirect), the variables were analyzed through a two-way ANOVA analysis using the SPSS v. 23.0 software (SPSS Inc.). The difference between the symptom score and the two variables was also determined with the same analysis. The effects were significant at $\mathrm{P} \leq 0.05$.

\section{RESULTS}

\section{The survey results}

For 2015-2016, the survey was carried out in the Kokzhar, Vorontsovka, and Ak-Beshim villages and Bishkek city of the Chy region. In spring and early summer, observations revealed the following symptoms on stems and spurs: sunken, dead areas of bark that often accompanied by gummy ooze. If the infection had spread all-round, the branches died rapidly. On leaves of apricots and plums, small brown spots appeared which were often round and fell out later through leave holes (shothole). Bacterial canker can sometimes kill larger branches or whole trees (Figure1, A and B). As such, the infected fruit often develop depressed spots with dark centers and sometimes have underlying gum pockets. Ulcers and cracks on the bark reached up to one and a half meters. The degree of damage was estimated on a 5point scale, and the lesions were about 2 points. While in the plantations of wild apricots, (Ak-Beshim village) the degree of damage did not exceed 1 point. In observed sites $P$. syringae, pv. syringae isolates were obtained from infected organs of pome trees like Peach (Prunus persica), Cherry (Prunus subgen), Plum (Prunus salicina). 
The disease incident caused by $P$. syringae pv. syringae has reached to $80-90 \pm 0.093 \%(\mathrm{P} \leq 0.05)$ in these analyzed trees. In addition, Xanthomonas sp. and Stenotrophomonas sp. were isolated from diseased part of trees, constantly accompanying the main pathogen. Such types of disease as bacterial leaf shot hole, bacterial fruit shot hole, bacterial canker, fruit necrosis and fruit canker were dominated (Table 2).

Table 2. Disease outbreaks on pome plants caused by the P. syringae pv. syringae complex reported in 2015-2017 in different regions of Kyrgyzstan.

\begin{tabular}{|c|c|c|c|c|c|c|}
\hline Region & year & Host trees & Disease & Pathogen & $\begin{array}{c}\text { DI } \\
(\%)\end{array}$ & $\begin{array}{c}\text { Concomitant } \\
\text { bacterial species }\end{array}$ \\
\hline Batken & 2016 & Apricot (Prunus armeniaca) & Bacterial leaf spot & P.s. pv. syringae & 80 & $\begin{array}{l}\text { Erwinia sp. } \\
\text { Stenotrophomonas sp. }\end{array}$ \\
\hline Batken & 2016 & Apricot (Prunus armeniaca) & Stem necrosis & P.s. pv. syringae & 60 & $\begin{array}{l}\text { Stenotrophomonas sp. } \\
\text { Erwinia sp. }\end{array}$ \\
\hline Batken & 2016 & Apricot (Prunus armeniaca) & Fruit necrosis & P. s. pv. syringae & 60 & $\begin{array}{l}\text { Stenotrophomonas sp. } \\
\text { Pseudomonas sp. }\end{array}$ \\
\hline Chui region & $\begin{array}{l}2015 \\
2016\end{array}$ & Peach (Prunus persica) & $\begin{array}{l}\text { Bacterial leaf shot } \\
\text { hole }\end{array}$ & P.s. pv. syringae & 80 & $\begin{array}{l}\text { Xanthomonas sp. } \\
\text { Erwinia sp. }\end{array}$ \\
\hline Chui region & $\begin{array}{l}2015 \\
2016\end{array}$ & Peach (Prunus persica) & Bacterial Canker & P.s. pv. syringae & 60 & $\begin{array}{l}\text { Pseudomonas sp. } \\
\text { Xanthomonas sp. }\end{array}$ \\
\hline Chui region & $\begin{array}{l}2015 \\
2016\end{array}$ & Cherry (Prunus subgen) & $\begin{array}{l}\text { Bacterial leaf shot } \\
\text { hole }\end{array}$ & P.s. pv. syringae & 80 & $\begin{array}{l}\text { Pseudomonas sp. } \\
\text { Stenotrophomonas sp. }\end{array}$ \\
\hline Chui region, & $\begin{array}{l}2015 \\
2016\end{array}$ & Cherry (Prunus subgen) & Bacterial Canker & P.s. pv. syringae & 90 & $\begin{array}{l}\text { Pseudomonas sp. } \\
\text { Erwinia amylovora }\end{array}$ \\
\hline Bishkek city & $\begin{array}{l}2015 \\
2016\end{array}$ & Plum (Prunus salicina) & Fruit necrosis & P.s. pv. syringae & 80 & $\begin{array}{l}\text { Xanthomonas sp. } \\
\text { Erwinia sp. }\end{array}$ \\
\hline Bishkek city & $\begin{array}{l}2015 \\
2016\end{array}$ & Plum (Prunus salicina) & Fruit Canker & Xanthomonas sp. & 80 & $\begin{array}{l}\text { Xanthomonas } s p . \\
\text { Pseudomonas } s p .\end{array}$ \\
\hline $\begin{array}{l}\text { Issyk-Kul } \\
\text { region }\end{array}$ & $\begin{array}{l}2016 \\
2017\end{array}$ & Apricot (Prunus armeniaca) & $\begin{array}{l}\text { Bacterial Canker on } \\
\text { the trunk, limbs }\end{array}$ & P.s. pv. syringae & 90 & $\begin{array}{l}\text { Pseudomonas sp. } \\
\text { Erwinia sp. }\end{array}$ \\
\hline $\begin{array}{l}\text { Issyk-Kul } \\
\text { region }\end{array}$ & $\begin{array}{l}2016 \\
2017\end{array}$ & Apricot (Prunus armeniaca) & Fruit Canker & P.s. pv. syringae & 90 & $\begin{array}{l}\text { Pseudomonas sp. } \\
\text { Erwinia sp }\end{array}$ \\
\hline Bishkek city & $\begin{array}{l}2015- \\
2017\end{array}$ & Plum (Prunus salicina) & $\begin{array}{l}\text { Bacterial leaf shot } \\
\text { hole }\end{array}$ & P.s. pv. syringae & 90 & $\begin{array}{l}\text { Pseudomonas sp. } \\
\text { Erwinia sp }\end{array}$ \\
\hline Bishkek city & $\begin{array}{l}2015- \\
2017\end{array}$ & Apricot (Prunus armeniaca) & $\begin{array}{l}\text { Bacterial Canker on } \\
\text { the trunk, limbs }\end{array}$ & P. s. pv. syringae & 90 & $\begin{array}{l}\text { Pseudomonas sp. } \\
\text { Erwinia sp. }\end{array}$ \\
\hline
\end{tabular}

DI= Disease Incidence, $P$. s. pv. syringae $=$ Pseudomonas syringae pv. syringae

During 2016-2017, in the Issyk-Kul region, the diseases were found in old apricot trees (Prunus armeniaca), but the greatest distribution was observed in Tosor village, where almost every tree was affected by bacterial canker, and even young seedlings were injured. When cutting the damaged stem, the outer layers of the wood were often stained a brown color in contrast to the normal white, but the inner wood (xylem) was not discolored except in the more severe cases (Figure 1C and D). The degree of damage was estimated: in orchards of Balykchi on a 3-point scale, Bokonbaevo on
1 point, and Tosor on 4 points, while Khadjisai and Zhargylchak on 3 points.

The disease incidence caused by $P$. syringae pv. syringae has reached up to $90 \%(\mathrm{P} \leq 0.05)$ in the analyzed diseased part of apricot trees. The symptoms of bacterial canker on the trunk and limbs, fruit canker were strongly differed in unarmed observation and dominated among other symptoms. Along with the main causative agent, other bacteria species like Pseudomonas sp. Erwinia sp. were isolated into a pure culture; they can be considered as saprophytic or facultative pathogens 
species that occupy a specific niche in the phyllosphere of trees (Table 2).

In the Batken region, the rapid development of this disease was observed during 2015-2016, and the degree of damage was estimated on a 3-point scale. Bacterial leaf spot, stem necrosis, fruit necrosis were the most spread diseases in these served sites. The disease incident caused by $P$. syringae pv. syringae has made about $60-80 \pm 0.092 \%(\mathrm{P} \leq 0.05)$ in the analyzed diseased part of apricot trees. Stenotrophomonas sp. Erwinia sp. bacteria were isolated with $P$. syringae pv. syringae isolates frequently.
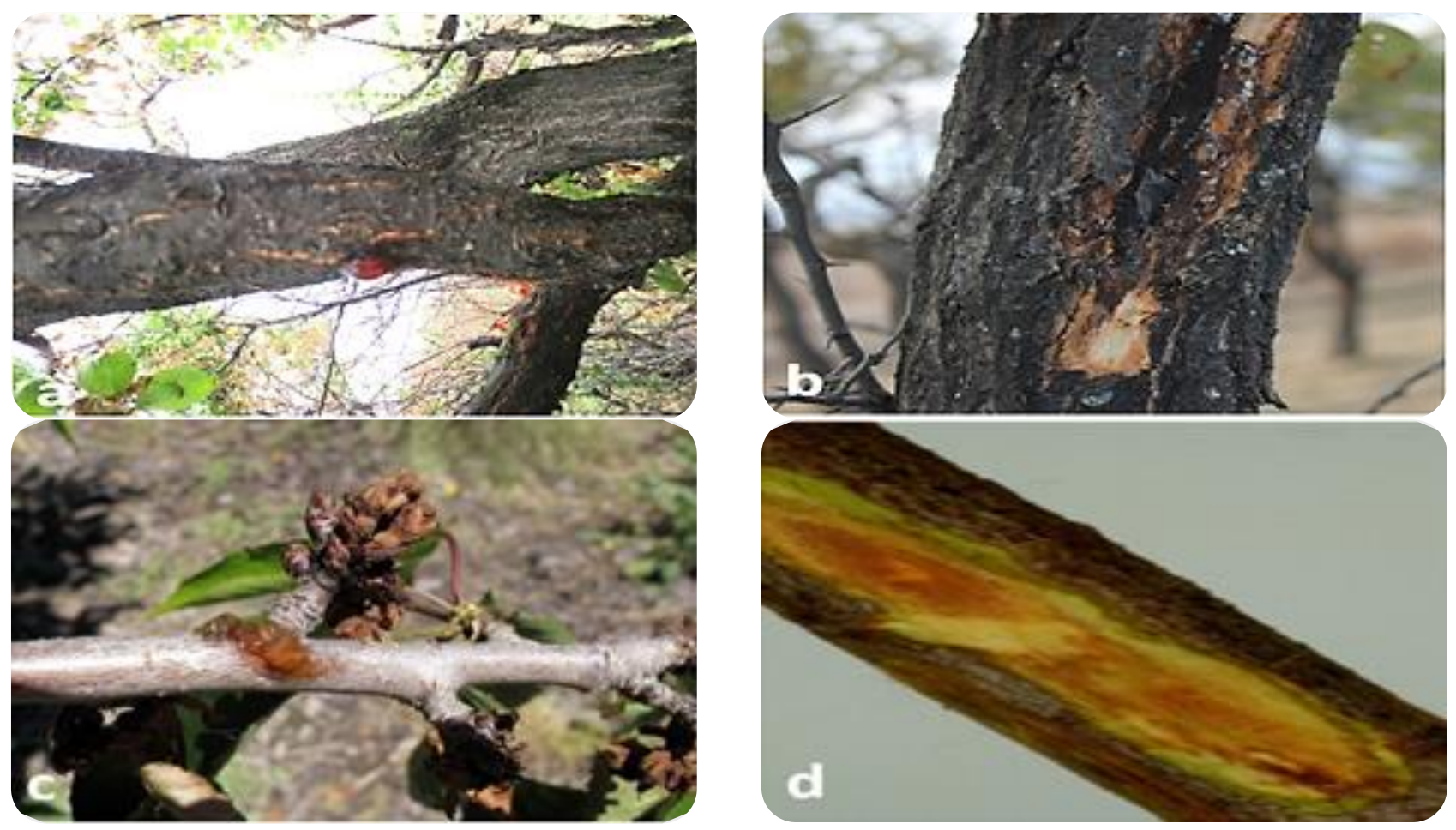

Figure 1: Symptoms of bacterial canker as shown in the diseased barks of old apricot trees $(a, b)$ and of young apricot trees (c, d).

\section{The phenotypic characterization of Pseudomonas syringae pv. syringae isolates}

A total of twelve $P$. syringae pv. syringae isolates have been detected to their biochemical and pathogenic properties and the prevalence of these bacteria in a phylloplane environment indicates their competence longevity (Table 3).

The characterization of colonies formation and cultural properties on different media

All obtained isolates on King B medium formed typical for the species $P$. syringae pv. syringae colonies: roundish, whitish-gray, up to $5 \mathrm{~mm}$ in diameter, with a conical-raised center, a shaft-shaped slightly-wavy edge, semi-translucent, with a denser center and a smooth or slightly granular structure ( 0 -form) (Figure $2 \mathrm{~A}$ and $\mathrm{B}$ ). $P$. syringae J-5 strain on Levan medium plates: at room light and at UV light. As shown in Figure 2 (C and D), bacterial cancer pathogen, such as the bacterial fire blight, has formed white colonies on the Levan medium. In order to differentiate between these pathogens, the UV light is required. Ps. syringae bacteria affected by this light have produced blue-green pigment, and while Erwinia amylovora in the presence of UV light remains unchanged. Figure 3 has shown the colonies $P$. syringae isolated from Plum (Prunus salicina) on different mediums.

The phytopathogenic Pseudomonas strains were identified according to Lelliott et al. (1966), who devised a determinative scheme that based on simple laboratory tests. The average growth time of the $P$. syringae isolates from apricot, plum, cherry and peach under laboratory conditions was 1 and 3 hours at $28{ }^{\circ} \mathrm{C}$. All isolated strains have grown very intensely at $15^{\circ} \mathrm{C}$; especially the two strains of BT- 5 and A2.2 that indicated to ability not lose their virulence at $15^{\circ} \mathrm{C}$. 
Table 3: Characteristics of Pseudomonas syringae colonies growing on different mediums.

\begin{tabular}{|c|c|c|c|c|c|}
\hline Sr. & $\begin{array}{l}\text { P. syringae } \\
\text { strains }\end{array}$ & $\begin{array}{l}\text { Source plant for } \\
\text { isolation }\end{array}$ & GPA medium & Levan medium & King B medium \\
\hline 1 & $J-5$ & Apricot Prunus armeniaca & $\begin{array}{l}\text { Dry and dirty white } \\
\text { color colonies }\end{array}$ & Yellow color colonies & $\begin{array}{l}\text { Pale color, rough } \\
\text { colonies }\end{array}$ \\
\hline 2 & BO & Apricot Prunus armeniaca & Yellow colonies & Mucous, gold like colonies & Mucous yellow \\
\hline 3 & $\mathrm{SCH}$ & Peach (Prunus persica), & Yellow colonies & Mucous yellow & $\begin{array}{l}\text { Mucous yellow } \\
\text { colonies }\end{array}$ \\
\hline 4 & $\mathrm{C} 2.3$ & Plum (Prunus salicina & Rough yellow colonies & Yellow colonies & $\begin{array}{l}\text { Dry and dirty white } \\
\text { rough colonies }\end{array}$ \\
\hline 5 & BT-5 & Cherry (Prunus subgen) & $\begin{array}{l}\text { Dirty white color } \\
\text { colonies }\end{array}$ & Mucous yellow colonies & Mucous yellow colonies \\
\hline 6 & A2.2 & Apricot Prunus armeniaca & Small dot-like colonies & White small dot colonies & $\begin{array}{l}\text { Dry and dirty white } \\
\text { rough colonies }\end{array}$ \\
\hline 7 & $\mathrm{SCH}-2$ & Peach (Prunus persica) & Yellow colonies & Mucous yellow colonies & Mucous yellow colonies \\
\hline 8 & K-4 & Cherry (Prunus subgen) & Yellow color colonies & Light yellow colonies & Mucous yellow colonies \\
\hline 9 & AT-2 & Cherry (Prunus subgen) & $\begin{array}{l}\text { Dairy-like, spherical } \\
\text { colonies }\end{array}$ & Yellow color colonies & $\begin{array}{l}\text { Dry and dirty white } \\
\text { rough colonies }\end{array}$ \\
\hline 10 & $\mathrm{C} 2.5$ & Plum (Prunus salicina & Rough yellow colonies & Yellow colonies & $\begin{array}{l}\text { Dry and dirty white } \\
\text { rough colonies }\end{array}$ \\
\hline 11 & A1.4 & Apricot Prunus armeniaca & Dirty white colonies & Pale yellow colonies & $\begin{array}{l}\text { Dry and dirty white } \\
\text { rough colonies }\end{array}$ \\
\hline 12 & $\mathrm{C} 2.5$ & Plum (Prunus salicina & Rough yellow colonies & Yellow colonies & $\begin{array}{l}\text { Dry and dirty white } \\
\text { rough colonies }\end{array}$ \\
\hline
\end{tabular}
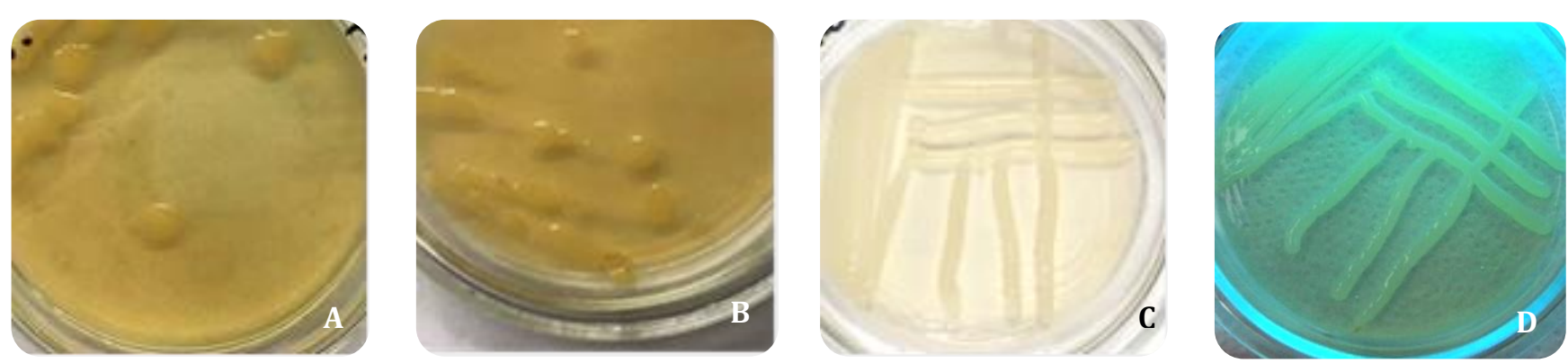

Figure 2. Colonies of bacterial canker pathogen on King B medium: A -colonies of P. syringae sp. isolates from Batken apricot; B - colonies of $P$. syringae sp.isolates from peach tree. C- colonies of $P$. syringae sp. isolates on the Levan medium, at room light; D- colonies of $P$. syringae sp. isolates on the Levan medium, at UV light.

The biochemical characterization of Pseudomonas syringae isolates

Phytopathogenic Pseudomonas are divided into pathotypes according to five biochemical tests. This test is abbreviated as the LOPAT test.

1. Levan formation (L); 2. Oxidase production (0); 3. Maceration of plant tissue (P) 4. Arginine dihydrolase production (A); 5. Hypersensitive reaction in tobacco (T) There are fifty $P$. syringae pathotypes distinguished according to the above tests ( $\mathrm{L}+, \mathrm{O}-, \mathrm{P}-, \mathrm{A}-, \mathrm{T}+$ ), which cause diseases in 180 plant species (Lamichhane et al., 2014; Lamichhane et al., 2015).

Based on LOPAT (levan production, oxidase test, potato rot, arginine dihydrolase and tobacco hypersensitive reaction) and GATTa's (gelatin liquefaction, aesculin hydrolysis, tyrosinase activity and Na-tartrate utilization), group tests were identified with the phenotypic (biochemical and physiological) 
characteristics. Almost all the studied pathogen strains were able to liquefy gelatin moderately; the liquefaction process started in five days and produced hydrogen sulphide (Table 4). However, all strains had simple nutritional requirements and may have utilized many carbon sources such as glucose, succinate, glycerol, fumarate, and pyruvate as well as simple amino acids and small peptides. This broad diet may allow the colonization of diverse host plants as well as survival in water including rain, snowmelt, streams, and rivers.
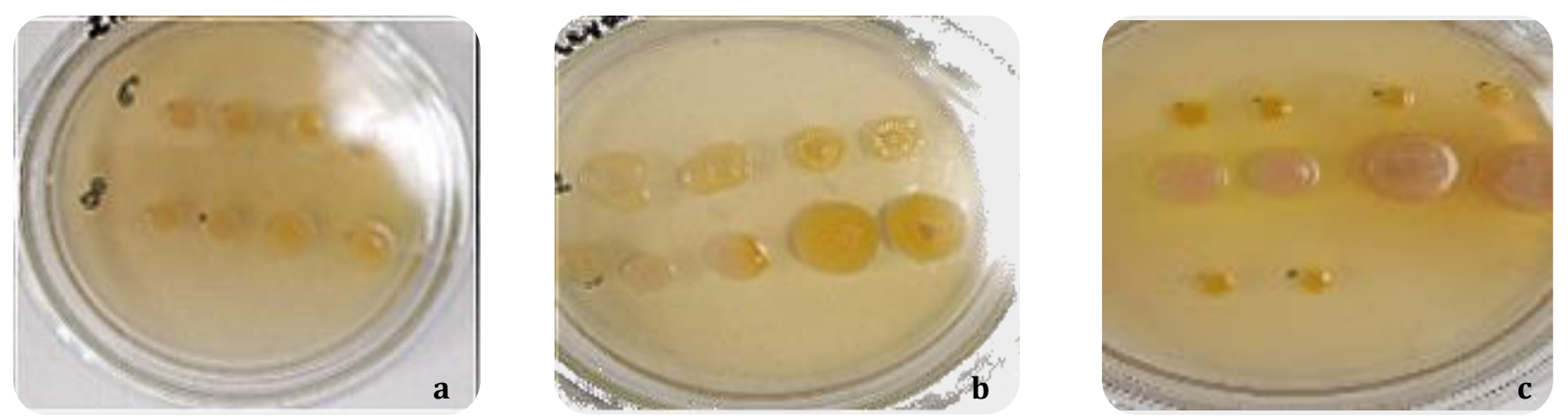

Figure 3: The colonies of Pseudomonas syringae bacterium isolated from Plum (Prunus salicina): on GPA medium (a); on the Levan medium (b) ; on Ps. agar medium ( c).

Table 4: Biochemical tests for Pseudomonas syringae bacterium (n=3).

\begin{tabular}{|c|c|c|c|c|c|c|}
\hline \multirow{2}{*}{ S. \# } & \multirow{2}{*}{ Test name } & \multicolumn{5}{|c|}{ Pseudomonas syringae isolates } \\
\hline & & BO & $\mathrm{SCH}$ & C.2.3 & BT-5 & A2.2. \\
\hline 1 & Reduction of sugar compounds & + & - & - & - & - \\
\hline 2 & Catalase test & + & + & + & + & + \\
\hline 3 & Salinity resistance & + & + & + & + & + \\
\hline 4 & Pigment production & - & - & + & - & + \\
\hline 5 & $\mathrm{H}_{2} \mathrm{~S}$ production & - & - & $?$ & $?$ & $?$ \\
\hline 6 & Levan formation & + & + & + & + & + \\
\hline 7 & Maceration of potatoes tuber & - & - & - & - & - \\
\hline 8 & $\begin{array}{l}\text { The growth on yeasts extract } \\
\text { medium with } \mathrm{CaCO}_{3} \text { (YDC). }\end{array}$ & + & + & + & - & - \\
\hline 9 & The growth on King B medium & + & + & + & + & + \\
\hline 11 & Pectate degradation & + & + & + & - & - \\
\hline 12 & Gelatin liquefaction & + & + & + & + & + \\
\hline \multirow[t]{2}{*}{13} & $\begin{array}{l}\text { Hypersensitive reaction in } \\
\text { tobacco (Nicotiana tabaccum L.) }\end{array}$ & + & + & + & + & + \\
\hline & & $\begin{array}{l}\text { Ps. pv. } \\
\text { syringae }\end{array}$ & $\begin{array}{l}\text { Ps. pv. } \\
\text { syringae }\end{array}$ & $\begin{array}{c}\text { Ps. pv. } \\
\text { morsprunorum }\end{array}$ & $\begin{array}{l}\text { Ps. pv. } \\
\text { syringae }\end{array}$ & $\begin{array}{l}\text { Ps. pv. } \\
\text { syringae }\end{array}$ \\
\hline
\end{tabular}

Most phytopathogenic bacteria can produce several pectolytic enzymes, each of which can be encoded by a family of genes and exist in several isoforms that differ in the optimum $\mathrm{pH}$, temperature, and other properties. In our cases, the following strains were grown well on a pectin-containing medium: BO, K-4, SH-2 (Supplem. material, Figure 1, A, B, C and D). Almost all of obtained $P$. syringae isolates were grown well giving density colonies on hawthorn containing agar, some isolates were grown on currant containing media, nevertheless, on this medium, isolates could increase the mass of their colonies, maintaining their viability for several days. These results prove the presence of lyase pectate in $P$. syringae isolates, which is the main enzyme that destroys pectin FI binding in plant tissues.

The growth of Pseudomonas syringae isolates on media with different $\mathrm{pH}$

All the obtained isolates were able to grow in culture media with pH $6.0 ; 6.5 ; 7.0 ; 7.5$, giving enough thick, 
massive columns. As the data show (Figure 4 and Supplement. mater. Figure 4), all isolates within 48 hours giving an intensive $100 \%$ growth on solid medium and in liquid medium with all the abovementioned $\mathrm{pH}$ values. That indicating in the above- mentioned $\mathrm{pH}$ values, they can absorb nutrients and carry out normal metabolism. Such features of metabolism prove that these bacteria can infect fruit trees in all phases of development; young, developing, and ripe.



$0 \%$

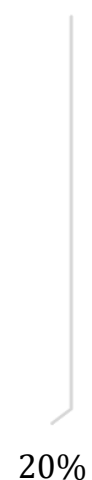

$20 \%$

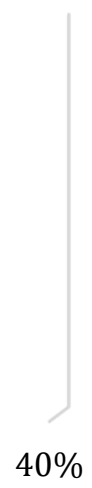

The growth intensity of bacteria cells in $48 \mathrm{~h}$

Figure 4: The growth intensity of Pseudomonas syringae isolates on media with different $\mathrm{pH}$ values.

The growth of Pseudomonas syringae isolates on media at different temperature

All studied isolates were grown in liquid LB medium at temperatures of $15{ }^{\circ} \mathrm{C}, 20^{\circ} \mathrm{C}, 27{ }^{\circ} \mathrm{C}, 35^{\circ} \mathrm{C}$ and after 48 hours, the cell titer was determined using a spectrophotometer. Temperature is an important factor directly affecting the virulence of the bacterial canker pathogen. Enzymes of this bacterium involved in pathogenesis are active at a certain temperature regime. As phytopathogens, Ps. syringae isolates were able to grow well at $15{ }^{\circ} \mathrm{C}$ temperature, in particular, BT-5 and A2.2 isolates (Figure 5). The ability to survive at relatively low temperatures provides the prevalence of potentially pathogenic strains of Ps. syringae in non-plant substrates such as irrigation waters or in symptomless weeds, wild plants and ground covers (Morris et al., 2019).

\section{The sensitivity of Pseudomonas syringae isolates to} antibiotics

Determining the sensitivity of bacteria to antibiotic substances gives rise to the treatment of diseased plants from bacterial infections. In the appointment, effective treatment is necessary to select antibiotics that can actually suppress the pathogen. For this, first, in laboratory conditions, it is necessary to determine the sensitivity of bacteria to various types of antibiotics.

As the results have shown, all tested Ps. syringae isolates were sensitive to erythromycin, ofltoxacin, and penicillin at least in the $50 \mathrm{mg}$ dose; the lysis zones around the wells made up $12-22 \pm 0,02 \mathrm{~mm}$ (Supplem. material, Figure 2).The sensitivity of the of the bacteria to antibiotics appeared at different times, for example, after two or three days. In our studies, almost all bacterial strains showed sensitivity to antibiotics, forming 10-20 $\pm 0,01 \mathrm{~mm}$ lysis zones after two days.

In particular, the bacteria turned out to be mediumsensitive, since bacterial colonies continued to grow after some time. The determination of the sensitivity of Pseudomonas syringae isolates to antibiotics in laboratory experiments is the first stage to search for non-chemical agents to combat the disease.

Artificial infection of mature pear fruits to determine the Pseudomonas syringae virulence

Pathogenic bacteria use a variety way to infect and multiply in host cells. For example, it is well known that Erwinia amylovora cells can produce mucous exudate in immature pear fruits, when $P$. syringae cells can form a dry dark necrosis in fruits. Through the White method (Johansson et al., 2015), the mature pear fruits were infected with $P$. syringae culture. According to the results of these tests, P. syringae local strains isolated from apricots, peaches, cherry and plums showed a clear symptom of necrosis in 
mature fruits. Within one week, brown necrotic spots appeared in pear fruits, which is a basic symptom of bacterial cancer. Initially, there were brown and eventually black color spots covering the fruits (Figure 6a). This indicated that P. syringae isolates with virulence properties could produce compounds such as siderophore pyoverdine and phytotoxin, similar to syringomycin, which cause dark dry decay (Jones et al., 2007; Taguchi et al., 2009).

Artificial infection of immature cherry and plum fruits to determine the Pseudomonas syringae virulence

The new spring season immature cherry and apricot
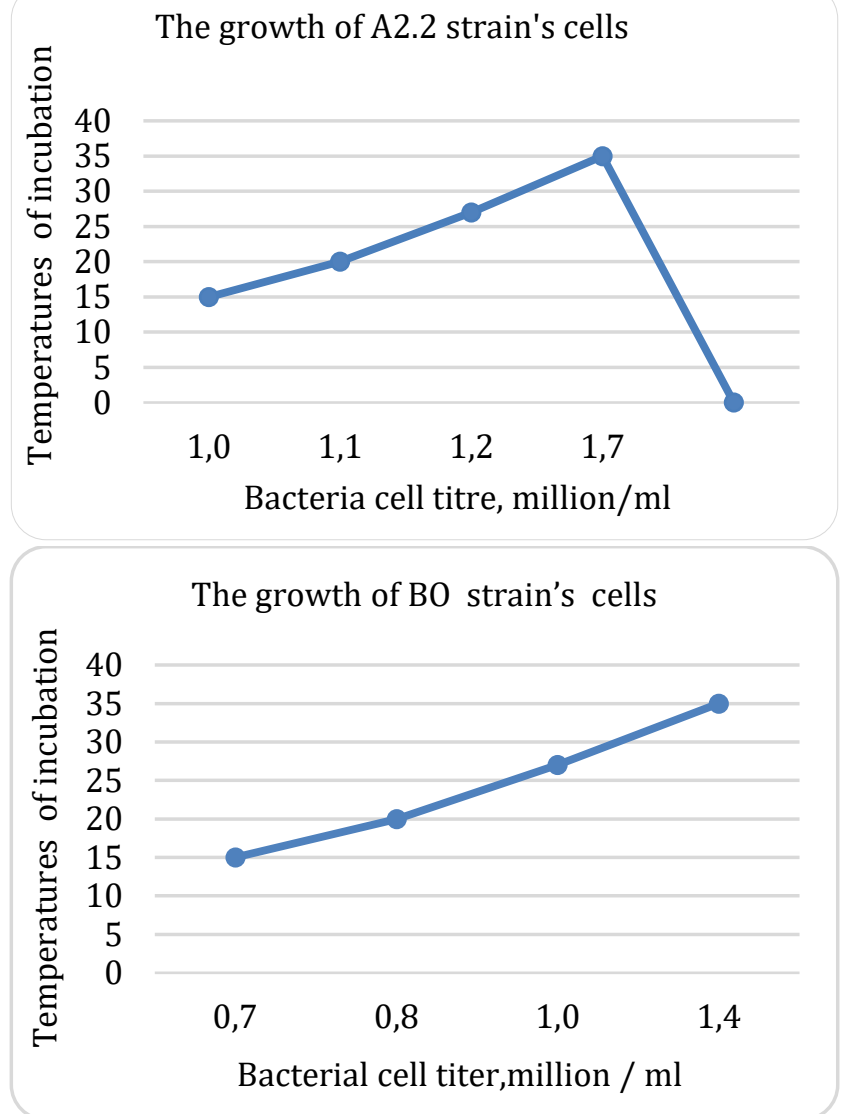

fruits of different cultivars were selected for artificial infection tests. As shown in Figure $6 \mathrm{~b}$ and c, the typical symptoms of bacterial cancer appeared in fruits and brown spots formed around the inoculated points; on the other hand, where sterile water was injected in control, there were no signs of spots. Particularly, the strains S2-3, Sh -ch, and A 2.2 showed clearly visible spots on the surface of cherry fruits, whereas all tested strains demonstrated brown-colored spots on the surface of plum fruits. These results confirm that the detected local $P$. syringae isolates can cause bacterial cancer symptoms. The fruits inoculated with sterile water in control experiments presented in Figure 7.

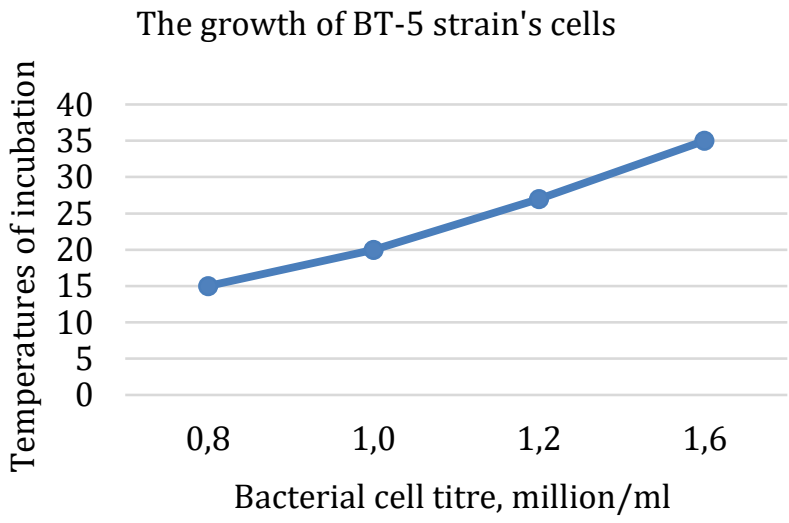

The growth of K-4 strain's cells

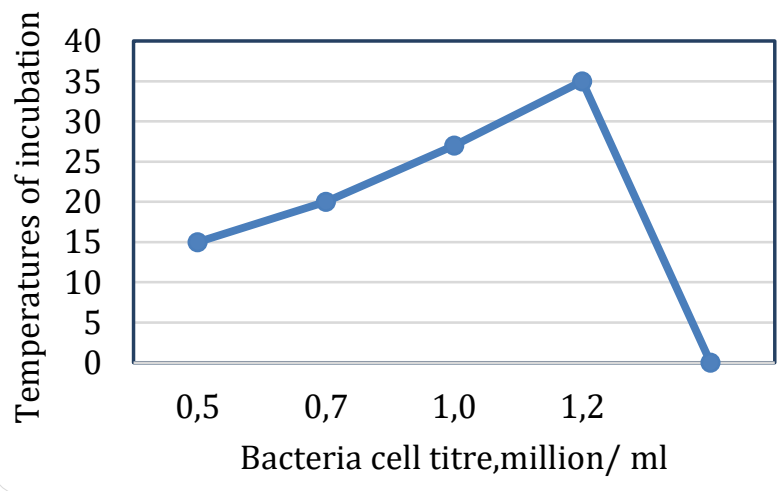

Figure 5. The growth intensity of Ps. syringae isolates at different temperatures in liquid LB medium. 

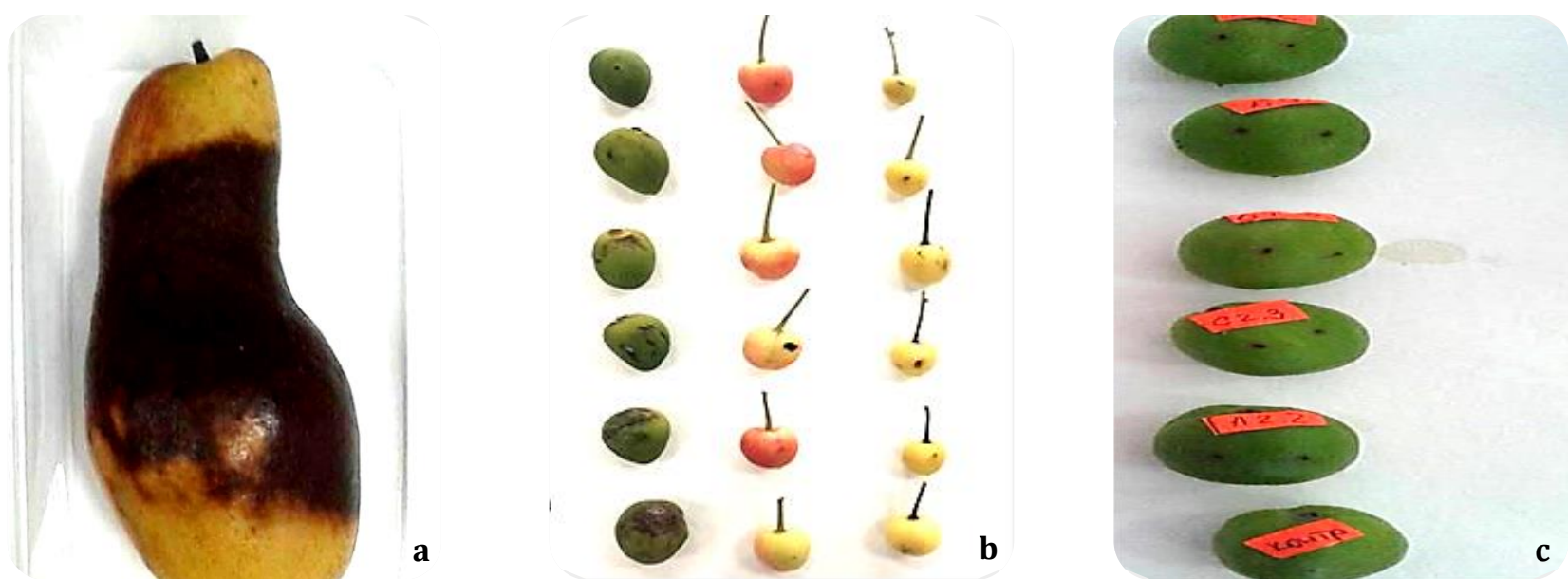

Figure 6: Pseudomonas syringae BA strain isolated from Batken Apricot have caused the necrosis in mature pear fruits (a); b and c- the plum, cherry and apricots fruits in artificial infect biotests.
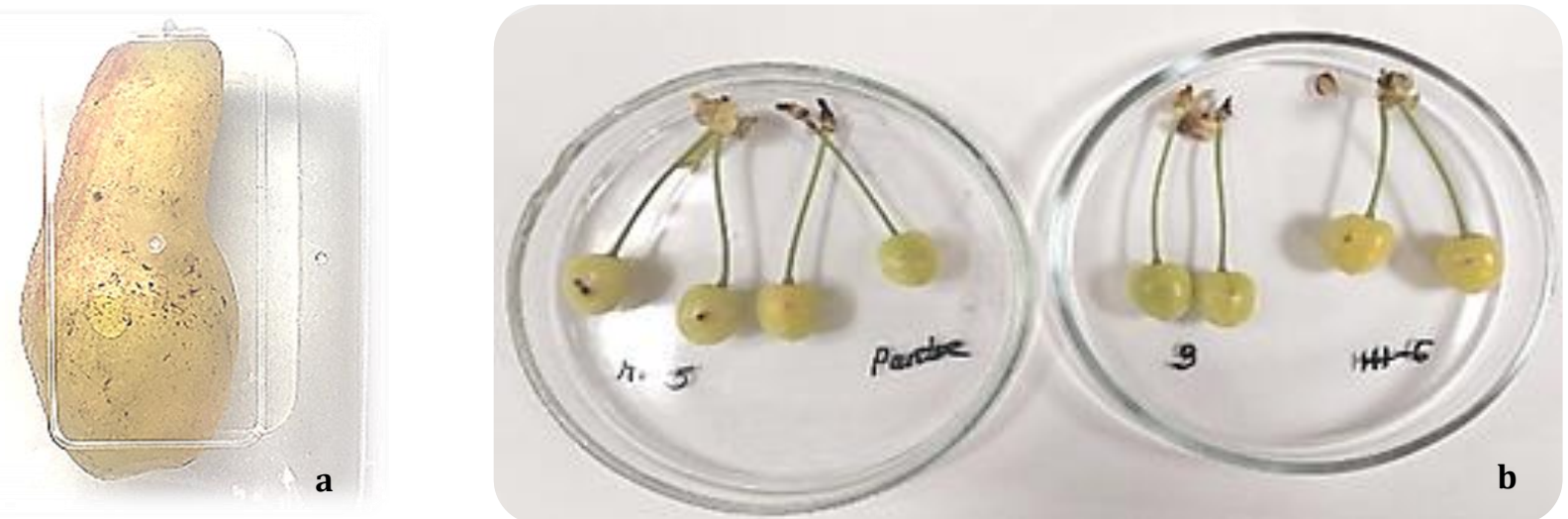

Figure 7: Mature pear fruit in control, inoculated with sterile water (a); cherry fruits in control, inoculated with sterile water (b).

The hypersensitivity of plant tissue to Pseudomonas syringae

The necrosis patches on surface of the tobacco leaves appeared within 24 hours. The most obtained Pseudomonas syringae isolates induced rapid HR and death (within 12-24 h) of tobacco leaf cells at the site of pathogen invasion. The induction of HR requires live and metabolically active bacteria as well as physical contact between plant and bacterial cell walls. According to Figure 3 (Supplemen. material. Figure 3), the BT-5 strain (isolated from Balykchy place) has demonstrated the most visible hypersensitivity reaction of tobacco leaves. Subsequently, a more active reaction of tobacco leaves was caused by Sh-4 (isolated from the peaches) and C2-3 (isolated from the plums).

\section{Classic analysis based on the polymerase chain reaction}

Molecular methods are currently the most widely adapted and considered very useful for the identification of bacterial canker causal agents and studying their genetic diversity. 16S rRNA gene analyses has found the association of epiphytic microflora consisting except of this pathogen bacteria, gram-negative bacteria from Stenotrophomonas, Xanthomonas, Erwinia, genera, and gram positive bacteria from the Bacillus genus (Figure 8).

The determination of the antagonistic effects of Streptomyces against Pseudomonas syringae

As well known among the actinomycetes, the representatives of the Streptomyces genus are important, as they include substances with antagonistic properties against bacterial and fungal pathogens in addition to a bio-stimulating effect on seeds and seedlings of agricultural plants (Gupta et al., 1995; Kolla and Vijayalakshmi, 2009).

In this study, Streptomyces active strains from the laboratory collection were used for biotesting against 
this pathogen. The origin and cultural characteristics of the antagonists are shown in (Supplem. material, Table 1). The results obtained when using the touch method of the nutrient medium surface are shown in Table 5.

As the results of the research have shown, the antagonistic activity of different biocontrol strains was different. The strain Streptomyces bambargiensis SK-6.6 showed a strong antagonistic effect on $P$. syringae providing a complete inhibition of the growth and development of the colonies of this phytopathogen. Other biocontrol agents such as Streptomyces sp. C1-4 and Streptomyces sp. Pr-3 showed a hyper-parasitic effect, using the colonies of $P$. syringae as a source of nutrients, growing on the cells of pathogens.

\section{Screening of Streptomyces strains on apricot and black plum seedlings}

Five days after artificial infestation of the highly susceptible local variety of apricot and black plum seedlings the first signs of the disease's symptoms emerged: the leaf first appeared water-soaked; they next turned dark green, then wilted and finally turned brownish to black (Supplem. material, Figure 5). Seven days after infection, the seedlings' leaves were treated with Streptomyces C1-4 at a dose of $10^{6}$ spores $/ \mathrm{ml}$. A second treatment with the antagonist product was conducted seven days after the first treatment, using the same dose. 15 days after two applications of the antagonist product with a dose of $10^{6} \mathrm{spores} / \mathrm{ml}$, the number of recovered leaves has increased; the number of apricot healthy leaves reached $33 \pm 0.03$ (Figure 9).

On 15 days after two treatments with Streptomyces $s p$. C1-4, the number of infected leaves had not increased and progression of the disease had completely stopped, a diseased plant's tissue can begin to recover and function normally. When a biological product based on Streptomyces sp. C1-4 was used, the sick parts dried up and the uninfected parts were preserved in their natural state; the leaf tissue did not become rigid, as with a chemical drug. Thus, the biological antagonist affects only the pathogen and has no adverse effect on leaf tissue. This means that by stopping the progression of the disease, a diseased plant's tissue can begin to recover and function normally.

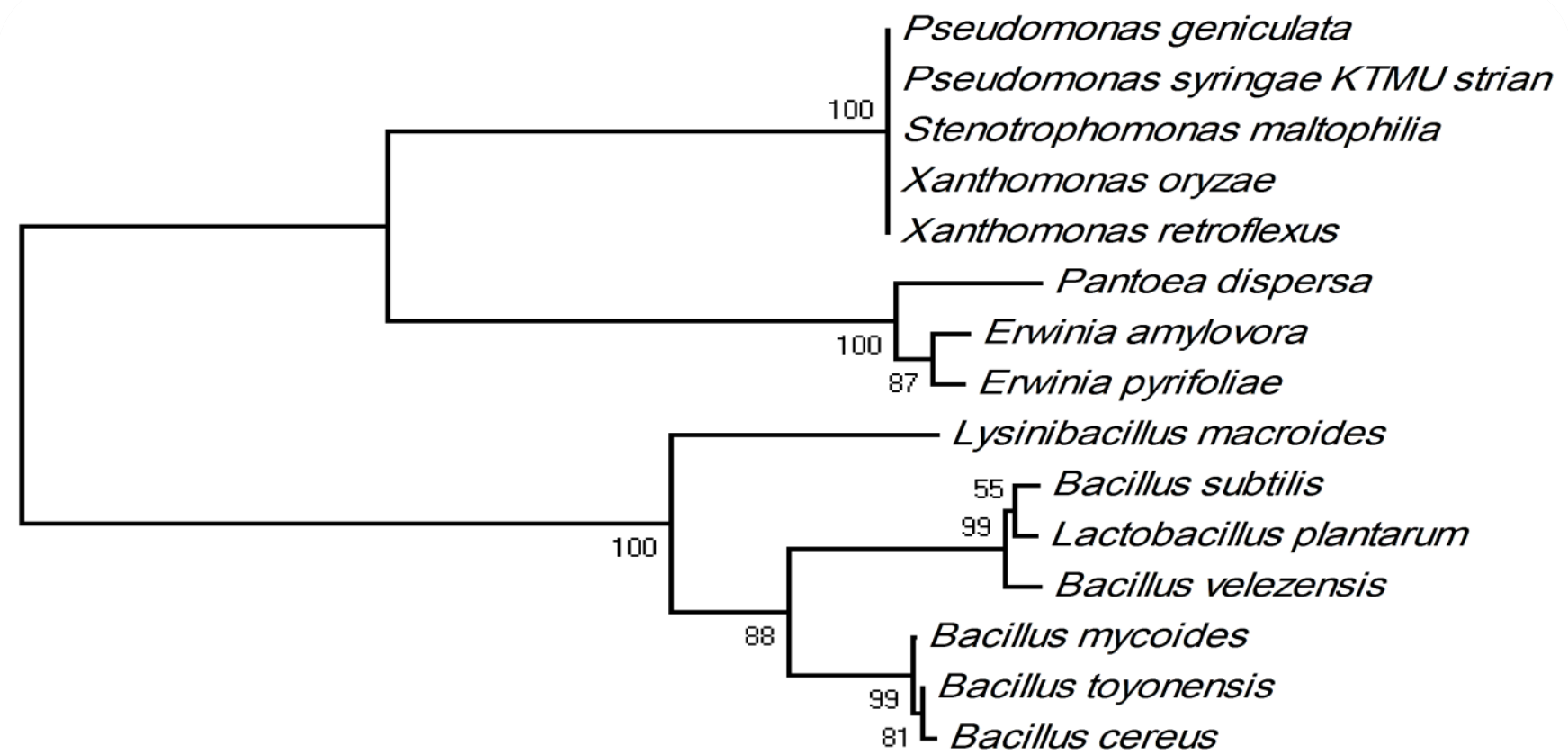

Figure 8: Phylogenetic tree produced from the I6S gene sequences showing the phylogenetic relationships of $P$. syringae KTMU strain with gram negative and gram-positive bacteria using the neighbor-joining method. Relevant bootstrap values (expressed as a percentage of 1000 replicates) are shown at branch points, and bar (0.02) changes per sequence position. 
Table 5: Antagonistic activity of Streptomyces species against bacterial blight pathogen in laboratory experiments ( $\mathrm{n}=3)$.

\begin{tabular}{|c|c|c|c|c|c|c|}
\hline \multirow[b]{2}{*}{$\begin{array}{l}\text { Test } \\
\text { culture }\end{array}$} & \multicolumn{6}{|c|}{ Antagonistic activity of the microorganisms after seven days } \\
\hline & $\begin{array}{l}\text { Streptomyces } \\
\text { diastochromogenes, } \\
\text { Sk-6 }\end{array}$ & $\begin{array}{l}\text { Streptomyces sp. } \\
\text { SK-2, } 2\end{array}$ & $\begin{array}{l}\text { Streptomyces } \\
\text { sp. } K K-4\end{array}$ & $\begin{array}{l}\text { Streptomyces } \\
\text { sp. C1-4 }\end{array}$ & $\begin{array}{l}\text { Streptomyces } \\
\text { sp. } K-3.3\end{array}$ & $\begin{array}{l}\text { Streptomyces } \\
\text { sp. Pr-3 }\end{array}$ \\
\hline $\begin{array}{l}P . \\
\text { syringae }\end{array}$ & $\begin{array}{l}\text { Inhibits growth of } \\
\text { pathogen }\end{array}$ & $\begin{array}{l}\text { Inhibits growth of } \\
\text { pathogen }\end{array}$ & $\begin{array}{l}\text { Shows no } \\
\text { activity }\end{array}$ & $\begin{array}{l}\text { Hyper } \\
\text { parasitism }\end{array}$ & $\begin{array}{l}\text { Shows } \\
\text { activity }\end{array}$ & $\begin{array}{l}\text { Hyper } \\
\text { parasitism }\end{array}$ \\
\hline
\end{tabular}

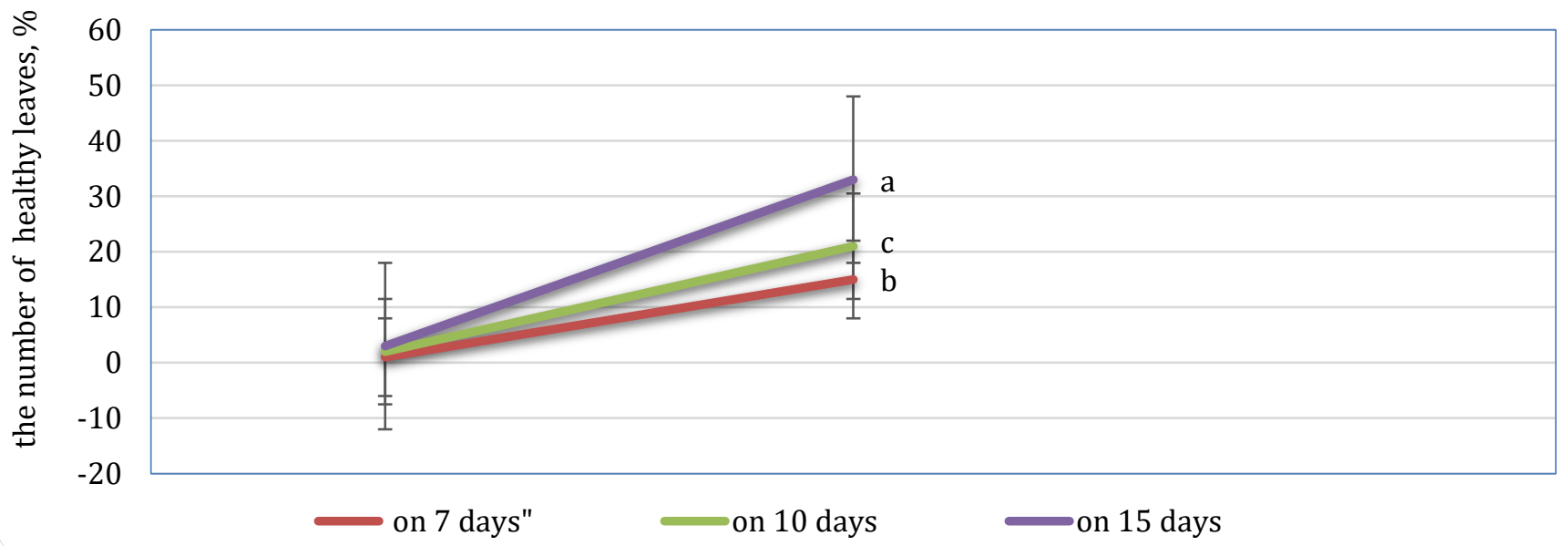

Figure 9: The increasing dynamic of healthy seedling's leaves in 15 days after two applications of Streptomyces C1-4 at a dose of $10^{6}$ spores / $\mathrm{ml}$; Values are means of $\pm \mathrm{SD}, \mathrm{n}=3, \mathrm{P} \leq 0.05$.

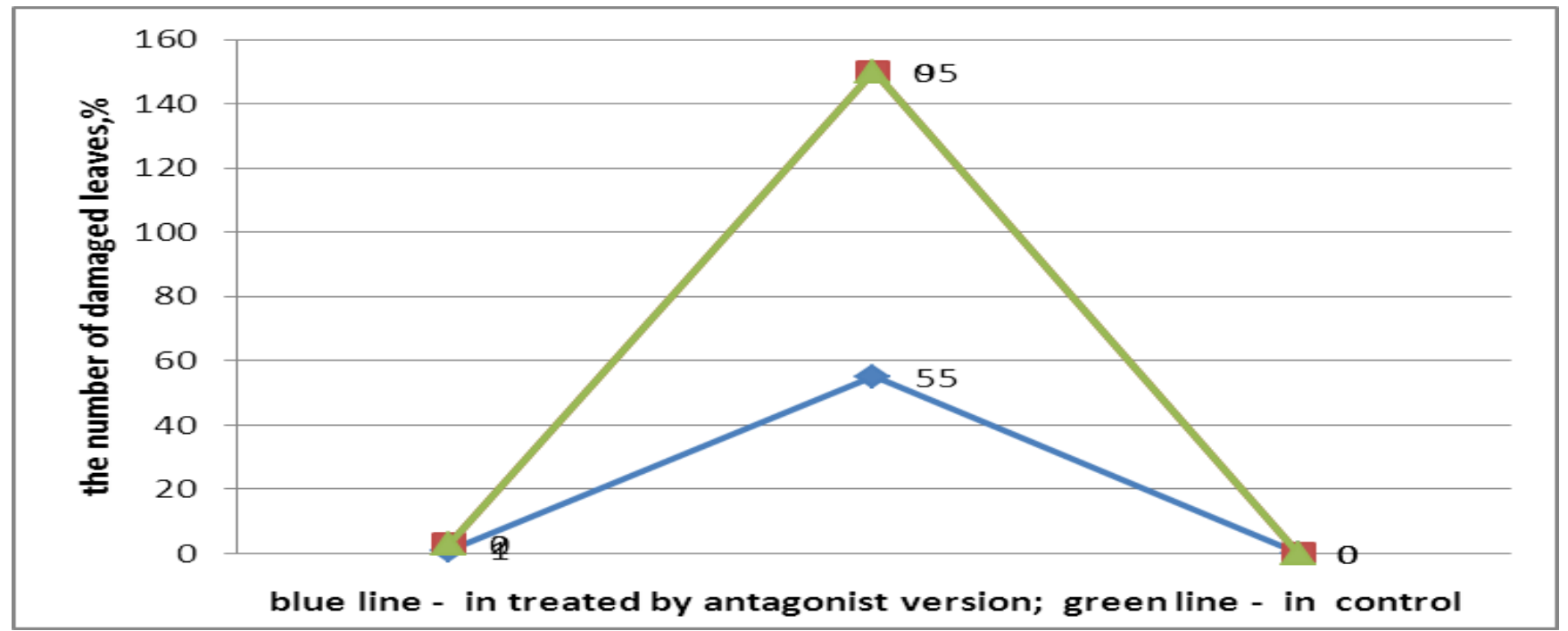

Figure 10: The decreasing dynamic of damaged seedling's leaves in 15 days after two applications of Streptomyces C14 at a dose of $10^{6}$ spores/ml. Values are means of $\pm S D, n=3, P \leq 0.05$.

\section{DISCUSSION}

P. syringae as an economically important pathogen remains largely unexplored and is far from properly understood in Kyrgyzstan. A lot is still unknown about the biology, host range, and ecological behavior of these bacteria on their host plants in the different ecosystems of the country. The present study was conducted for the first time in Kyrgyzstan's conditions for the study of the 
biology, ecology, and the prevalence of the pathogen in different regions with different climatic conditions. The monitoring survey for the symptomatic observation and collection of samples has revealed that in old stone plants planted over 30-40 years ago, the characteristic symptoms for bacterial cancer were strongly exhibited with large ulcer wounds and necrotic bark formations with the release of the exudate amber formation on the trunks and branches. The prolonged coexistence of the pathogen and the host under certain climatic conditions apparently could provide to both sides a survival status, but with a gradual weakening of the host plant. The used classical biochemical tests (LOPAT and GATTa's) have allowed us to isolate pure cultures of pathogen bacterium and identify the obtained isolates as a pathogen-P. syringae. Additionally, $16 \mathrm{Sr}$ RNA gene analysis has found the association of epiphytic microflora consisting except this pathogen bacteria, gram-negative bacteria from Erwinia, Xanthomanas, Stenotrophomonas genera, and gram-positive bacteria from the Bacillus genus. In such an association, this pathogen in a dominant ratio has adapted to coexist with its host plant and associated epiphytic bacteria in different climatic zones of the country. In the composition of the epiphytic microflora after the pathogen, the bacteria of the Stenotrophomonas genus was dominated. The role of this bacterium as a saprophyte or facilitative parasite contributing to the development of an outbreak must be clarified in future studies. According to the scientists, these bacteria can be found throughout the environment, particularly in close association with plants. S. maltophilia frequently cooccurs and forms multispecies biofilms with $P$. aeruginosa (Ryan et al., 2009). As reported by studies (Ercolani, 1991, 1985), that many phyllospheric bacteria are non-spore-forming, gram-negative or gram-positive heterotrophs, in general, the same species or group of bacteria are present on a wide range of plants, which was confirmed in our results. In addition, the studies have concluded that these groups are well adapted to the life in the phyllosphere, the conditions of which change daily, seasonally, while the pathogens on the diseased plants with obvious symptoms are predominated in such communities (Hirano and Upper, 2000). Our results also approved the above reports.

The long coexistence of the pathogen-plant system in the plant's homeland is a prime example for this bacterium since we found such a system between apricot and this bacterium in Batken's homeland, between peach varieties and this bacterium, between plum, cherry varieties and this bacterium in other regions; almost every local stone fruit variety had pathogen such as $P$. syringae. The composition of epiphytic microflora did not differ much in the regions of the republic, and no large differences were observed in the seasons of the year.

The dominance of $P$. syringae in all climatic conditions and seasons of the year indicates a wide range of the temperature of its growth. The optimum temperature turned out to be $28{ }^{\circ} \mathrm{C}$; at this temperature, the isolates isolated from apricot, peach, cherry and plum in just two to three hours, which gave a good growth of colonies on media. At a temperature of $15{ }^{\circ} \mathrm{C}$, they had intensive growth, which indicates that at this temperature, they do not lose their virulence. Another adaptive nature inherent in the isolated isolates is their ability to grow at different $\mathrm{pH}$ values, ranging from 6.0 to 7.5. Therefore, they affect plants in all phases of development, from budding to ripe fruit, as well as all age stages, spanning from seedlings to old, perennial trees. The results of biotests on mature and immature fruits of different stone fruits proved this ability. Unlike the Erwinia bacteria, this pathogen causes dry rot in the fruit. The presence of pectolytic enzymes detected by culturing them on media containing hawthorn and currant extracts proves that this pathogen is capable of destroying plant tissues in case of damage.

As well known, the causative agent of bacterial canker $P$. syringae bacteria affects more than 180 species of plants, among them herbaceous plants, vegetables, fruit crops. To limit the use of chemicals to protect plants from bacteriosis caused by $P$. syringae a constant search of safely to the environment and human health alternative means is underway.

For this purpose, the antibacterial activity of the growthstimulating rhizospheric bacteria (PGPR) such as $P$. aeruginosa, Bacillus stratosphericus, Paenibacillus polymyxa, B. subtilis and others against $P$. syringae was studied in vitro and in vivo experiments. Their overwhelming disease activity against $P$. syringae was reliably proven on tomatoes, kiwi fruit trees (Hong et al., 2016; Donati et al., 2018).

The biocontrol potential of soil and rhizospheric actinomycetes like Streptomyces in the regulation of pest damage by Pseudomonas syringae in fruit trees remains almost unexplored. According to studies, plant- 
associated actinomycetes play an important role in plant health due to ability to produce a wide range of secondary metabolites, like siderophores, various plant phytohormones such as auxins, cytokinins and gibberellins, and antibacterial and antifungal compounds (Cassán et al., 2001; Bottini et al., 2004; Solans et al., 2011). It has been proven that Streptomyces species are capable of exerting antifungal and antibacterial properties, protecting the plant root system from pathogens, and also suppressing diseases in soils (Gopalakrishnan et al., 2011; Xiao et al., 2002; Mendes et al., 2011; Cha et al., 2015).

In contrast to studies where Streptomycetes were used by introducing into the soil and around the root system of diseased plants, we used the Streptomyces strains against the bacterial canker pathogen by spraying the leaf surface and the crown of diseased seedlings of stone fruits, so biocontrol agents were introduced into epiphytic plant associations.

When signs of the disease appear on the leaves, double plentiful spraying of affected plants with a suspension of Streptomyces C1-4 strain (10 $10^{6}$ spores/ml) with an interval of 7 days prevented the development of the disease. Fifteen days after the biologic agent was applied twice, the plants fully recovered, new leaves and new twigs appeared. These results indicate that the Streptomyces C1-4 strain, introduced as a biological agent into the phyllosphere of diseased plants was able not only to colonize the epiphytic microflora, having an antibacterial effect but also increased the protective ability of the plants themselves, their potential to resist the disease, which is consistent with the data of other researchers (Conn et al., 2008; Tarkka et al., 2008; Kurth et al., 2014), they noted that Streptomycetes can cause a state of the increased protective ability of plants against pathogens, thereby providing plants with induced systemic resistance.

The growth of new shoots in a short period and the complete restoration of damaged leaves, branches also indicates to the growth-stimulating or phytohormonal effect of this agent on plants, as noted in the studies of (Cassán et al., 2001; Bottini et al., 2004). Thus, Streptomyces strain C1-4 was selected after in vitro tests as an effective antagonist and hyper-parasitic agent to $P$. syringae for spraying the diseased leaves of apricot and black plum seedlings. Streptomyces C1-4 showed a significant effect against $P$. syringae after two applications. A suitable time for this bio product's application is spring, when the symptoms of bacterial canker start to develop on the leaves of trees and the air temperature is $18-23^{\circ} \mathrm{C}$.

\section{CONCLUSIONS}

Therefore, our results on diagnosis of this pathogen can provide practical information useful for implementing efficient control measures in the current cropping season in the stone fruit gardens and in limiting future disease outbreaks of bacterial cancer in different regions of country. Also obtained results about capacity of the pathogen to adapt to climatic conditions, sensitivity to such biocontrol agents as Streptomyces species can encourage to develop a local bio-product based on this bioagent for spraying stone fruits with the initial manifestation of disease symptoms and to conduct preventive treatments in the fall and spring to increase the plant's resistance to pathogens. Our studies are suggesting the creation of induced plant immunity by spraying the phyllosphere with biological agents.

\section{ACKNOWLEDGEMENTS}

This research was supported within the framework of project "Surveillance and pathogen characterization of bacterial canker of stone fruits using biochemical and molecular methods and its bio-management" (PEREZGUERRERO TRUST Fund For SOUTH-SOUTH COOPERATION, UNDP).

\section{REFERENCES}

Agrios, G. N. 2005. Plant Pathology. Elsevier Academic Press: Burlington, Ma. USA.

Ahmed, R., M. Inam-ul-Haq, U. Shahzad, S. Hyder, S. Shahzaman, A. Khan, H. Aatif, A. Ahmad and A. Gondal. 2018. First report of bacterial canker caused by Pseudomonas syringae pv. morsprunorum race 1 on peach from Khyber Pakhtunkhwa province of Pakistan. Plant disease, 102: 2027-27.

Bais, H. P., R. Fall and J. M. Vivanco. 2003. Biocontrol of Bacillus subtilis against infection of Arabidopsis roots by Pseudomonas syringae is facilitated by biofilm formation and surfactin production. Plant physiology, 134: 307-19.

Berge, O., C. L. Monteil, C. Bartoli, C. Chandeysson, C. Guilbaud, D. C. Sands and C. E. Morris. 2014. A user's guide to a data base of the diversity of Pseudomonas syringae and its application to classifying strains in this phylogenetic complex. PLOS ONE, 9: e105547. 
Bottini, R., F. Cassan and P. Piccoli. 2004. Gibberellin production by bacteria and its involvement in plant growth promotion and yield increase. Applied microbiology and biotechnology, 65: 497503.

Braun-Kiewnick, A. and D. C. Sands. 2001. Pseudomonas. In: N W Schaad, J B Jones and W Chun (eds.), Laboratory Guide for Identification of Plant Pathogenic Bacteria. American Phytopathological Society Press: St. Paul, Minesota, USA.

Bultreys, A. and I. Gheysen. 1999. Biological and molecular detection of toxic lipodepsipeptideproducing Pseudomonas syringae strains and PCR identification in plants. Applied and Environmental Microbiology, 65: 1904-09.

Cassán, F. D., C. D. Lucangeli, R. Bottini and P. N. Piccoli. 2001. Azospirillum spp. metabolize [ 17,17-2H2] gibberellin A20 to [ 17,17-2H2] gibberellin A1 in vivo in dy rice mutant seedlings. Plant and Cell Physiology, 42: 763-67.

Cha, J.-Y., S. Han, H.-J. Hong, H. Cho, D. Kim, Y. Kwon, S.-K. Kwon, M. Crüsemann, Y. Bok Lee, J. F. Kim, G. Giaever, C. Nislow, B. S. Moore, L. S. Thomashow, D. M. Weller and Y.-S. Kwak. 2015. Microbial and biochemical basis of a Fusarium wilt suppressive soil. The ISME Journal, 10: 119-29.

Choi, O., B. Kang, S. K. Cho, J. Park, Y. Lee, W.-I. Kim, J. Marunga, I. Hwang and J. Kim. 2016. Identification of Pseudomonas syringae pv. syringae causing bacterial leaf blight of Miscanthus sinensis. Journal of Plant Diseases and Protection, 124: 97-100.

Conn, V. M., A. R. Walker and C. M. M. Franco. 2008. Endophytic actinobacteria induce defense pathways in Arabidopsis thaliana. Molecular PlantMicrobe Interactions, 21: 208-18.

Destéfano, S. A. L., L. M. R. Rodrigues, L. O. S. Beriam, F. R. A. Patrício, R. A. Thomaziello and J. RodriguesNeto. 2010. Bacterial leaf spot of coffee caused by Pseudomonas syringae pv. tabaci in Brazil. Plant Pathology, 59: 1162-63.

Donati, I., G. Buriani, A. Cellini, N. Raule and F. Spinelli. 2018. Screening of microbial biocoenosis of Actinidia chinensis for the isolation of candidate biological control agents against Pseudomonas syringae pv. actinidiae. Acta Horticulturae: 239-46.

Durairaj, K., P. Velmurugan, J.-H. Park, W.-S. Chang, Y.-J. Park, P. Senthilkumar, K.-M. Choi, J.-H. Lee and B.T. Oh. 2018. Characterization and assessment of two biocontrol bacteria against Pseudomonas syringae wilt in Solanum lycopersicum and its genetic responses. Microbiological Research, 206: 43-49.

Ercolani, G. L. 1985. Factor analysis of fluctuation in populations of Pseudomonas syringae pv. savastanoi on the phylloplane of the olive. Microbial Ecology, 11: 41-49.

Ercolani, G. L.. 1991. Distribution of epiphytic bacteria on olive leaves and the influence of leaf age and sampling time. Microbial Ecology, 21: 35-48.

Gardan, L., H. Shafik, S. Belouin, R. Broch, F. Grimont and P. A. D. Grimont. 1999. DNA relatedness among the pathovars of Pseudomonas syringae and description of Pseudomonas tremae sp. nov. and Pseudomonas cannabina sp. nov. (ex Sutic and Dowson 1959). International Journal of Systematic and Evolutionary Microbiology, 49: 469-78.

Gopalakrishnan, S., S. Pande, M. Sharma, P. Humayun, B. K. Kiran, D. Sandeep, M. S. Vidya, K. Deepthi and 0. Rupela. 2011. Evaluation of actinomycete isolates obtained from herbal vermicompost for the biological control of Fusarium wilt of chickpea. Crop Protection, 30: 1070-78.

Gupta, R., R. K. Saxena, P. Chaturvedi and J. S. Virdi. 1995. Chitinase production by Streptomyces viridificans: Its potential in fungal cell wall lysis. Journal of Applied Bacteriology, 78: 378-83.

Hirano, S. S. and C. D. Upper. 2000. Bacteria in the leaf ecosystem with emphasis on Pseudomonas syringae- A pathogen, ice nucleus, and epiphyte. Microbiology and Molecular Biology Reviews, 64: 624-53.

Hong, C. E., S. Y. Kwon and J. M. Park. 2016. Biocontrol activity of Paenibacillus polymyxa AC-1 against Pseudomonas syringae and its interaction with Arabidopsis thaliana. Microbiological Research, 185: 13-21.

Johansson, O. N., A. K. Nilsson, M. B. Gustavsson, T. Backhaus, M. X. Andersson and M. Ellerström. 2015. A quick and robust method for quantification of the hypersensitive response in plants. PeerJ, 3: e1469.

Jones, A. M., S. E. Lindow and M. C. Wildermuth. 2007. Salicylic acid, yersiniabactin, and pyoverdin production by the model phytopathogen Pseudomonas syringae pv. tomato DC3000: 
synthesis, regulation, and impact on tomato and Arabidopsis host plants. Journal of Bacteriology, 189: 6773-86.

King, E. O., M. K. Raney and D. E. Ward. 1954. Two simple media for the demonstration of pyocianin and fluorescin. Journal of Laboratory and Clinical Medicine, 44: 301-07.

Koike, S. T., E. I. Alger, L. Ramos Sepulveda and C. T. Bull. 2017. First report of bacterial leaf spot caused by Pseudomonas syringae pv. tomato on kale in California. Plant disease, 101: 504-04.

Kolla, N. J. P. and M. Vijayalakshmi. 2009. Chitinase production by Streptomyces sp. ANU 6277. Brazilian Journal of Microbiology, 40: 725-33.

Kurth, F., S. Mailänder, M. Bönn, L. Feldhahn, S. Herrmann, I. Große, F. Buscot, S. D. Schrey and M. T. Tarkka. 2014. Streptomyces-induced resistance against oak powdery mildew involves host plant responses in defense, photosynthesis, and secondary metabolism pathways. Molecular PlantMicrobe Interactions, 27: 891-900.

Lamichhane, J. R., A. Messéan and C. E. Morris. 2015. Insights into epidemiology and control of diseases of annual plants caused by the Pseudomonas syringae species complex. Journal of General Plant Pathology, 81: 331-50.

Lamichhane, J. R., L. Varvaro, L. Parisi, J.-M. Audergon and C. E. Morris. 2014. Disease and frost damage of woody plants caused by Pseudomonas syringae Advances in Agronomy. Elsevier. pp. 235-95.

Latorre, B. A. and A. L. Jones. 1979. Pseudomonas morsprunorum, the cause of bacterial canker of sour cherry in Michigan, and its epiphytic association with P. syringae. Phytopathology, 69: 335-39.

Lelliott, R. A., E. Billing and A. C. Hayward. 1966. A determinative scheme for the fluorescent plant pathogenic pseudomonads. Journal of Applied Bacteriology, 29: 470-89.

Lelliott, R. A. and D. E. Stead. 1987. Methods for the Diagnosis of Bacterial Diseases of Plants. Blackwell Scientific Publications: Oxford, Great Britain.

Little, E. L., R. M. Bostock and B. C. Kirkpatrick. 1998. Genetic characterization of Pseudomonas syringae pv. syringae strains from stone fruits in California. Applied and Environmental Microbiology, 64: 3818-23.
Mendes, R., M. Kruijt, I. de Bruijn, E. Dekkers, M. van der Voort, J. H. M. Schneider, Y. M. Piceno, T. Z. DeSantis, G. L. Andersen, P. A. H. M. Bakker and J. M. Raaijmakers. 2011. Deciphering the rhizosphere microbiome for disease suppressive bacteria. Science, 332: 1097-100.

Morris, C. E., C. Glaux, X. Latour, L. Gardan, R. Samson and M. Pitrat. 2000. The relationship of host range, physiology, and genotype to virulence on cantaloupe in Pseudomonas syringae from cantaloupe blight epidemics in France. Phytopathology, 90: 636-46.

Morris, C. E., J. R. Lamichhane, I. Nikolić, S. Stanković and B. Moury. 2019. The overlapping continuum of host range among strains in the Pseudomonas syringae complex. Phytopathology Research, 1: 116.

Morris, C. E., C. L. Monteil and O. Berge. 2013. The life history of Pseudomonas syringae: Linking agriculture to earth system processes. Annual review of phytopathology, 51: 85-104.

Mulet, M., J. Lalucat and E. García-Valdés. 2010. DNA sequence-based analysis of the Pseudomonas species. Environmental Microbiology, 12: 1513-30.

Polizzi, G., I. Castello, G. Parlavecchio and G. Cirvilleri. 2005. First report of bacterial blight of Strelitzia augusta caused by Pseudomonas syringae pv. lachrymans. Plant disease, 89: 1010-10.

Ryan, R. P., S. Monchy, M. Cardinale, S. Taghavi, L. Crossman, M. B. Avison, G. Berg, D. van der Lelie and J. M. Dow. 2009. The versatility and adaptation of bacteria from the genus Stenotrophomonas. Nature Reviews Microbiology, 7: 514-25.

Sedighian, N., M. Shams-Bakhsh, E. Osdaghi and P. Khodaygan. 2014. Etiology and host range of bacterial leaf blight and necrosis of squash and muskmelon in Iran. Journal of Plant Pathology, 96: 507-14.

Solans, M., G. Vobis, F. Cassán, V. Luna and L. G. Wall. 2011. Production of phytohormones by rootassociated saprophytic actinomycetes isolated from the actinorhizal plant Ochetophila trinervis. World Journal of Microbiology and Biotechnology, 27: 2195-202.

Stefani, E. and S. Loreti. 2014. Standard describes a diagnostic protocol for Pseudomonas syringae pv. actinidiae. EPPO Bulletin, 44: 360-75. 
Taguchi, F., T. Suzuki, Y. Inagaki, K. Toyoda, T. Shiraishi and Y. Ichinose. 2009. The siderophore pyoverdine of Pseudomonas syringae pv. tabaci 6605 is an intrinsic virulence factor in host tobacco infection. Journal of Bacteriology, 192: 117-26.

Tarkka, M. T., N. A. Lehr, R. Hampp and S. D. Schrey. 2008. Plant behavior upon contact with streptomycetes. Plant Signaling \& Behavior, 3: 917-19.

\section{CONFLICT OF INTEREST}

The authors declare that they have no conflicts of interest.

\section{AUTHORS CONTRIBUTIONS}

All the authors contributed equally to this work.
Vicente, J. G., J. P. Alves, K. Russell and S. J. Roberts. 2004. Identification and discrimination of Pseudomonas syringae isolates from wild cherry in England. European Journal of Plant Pathology, 110: 337-51.

Xiao, K., L. L. Kinkel and D. A. Samac. 2002. Biological control of Phytophthora root rots on alfalfa and soybean with Streptomyces. Biological Control, 23: 285-95.

Young, J. M. 210. Taxonomy of Pseudomonas syringae. Journal of Plant Pathology, 92: 5-14.

\section{SUPPLEMENTARY MATERIALS}
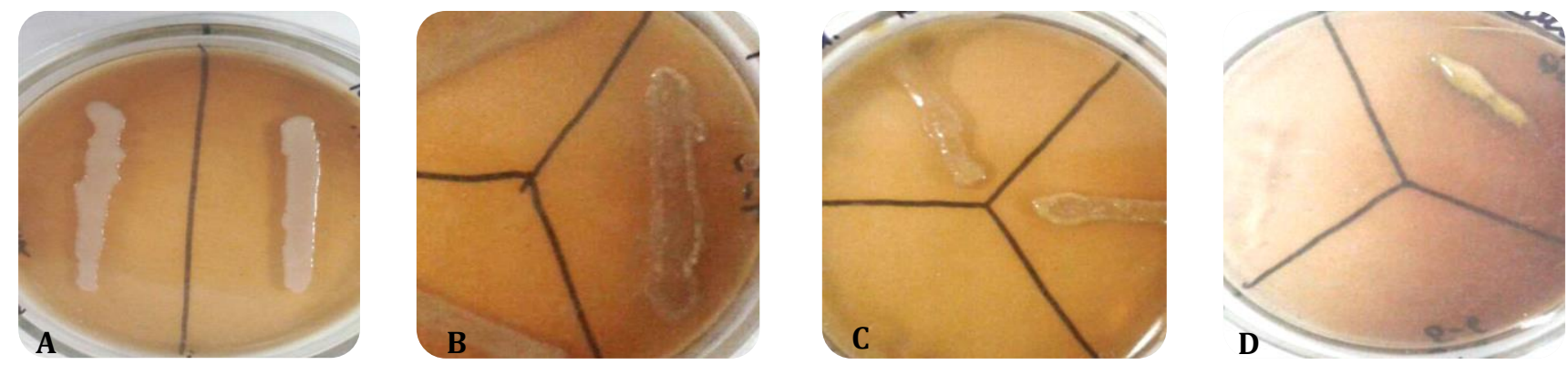

Supplementary Figure 1. The colonies of pectate degrading P. syringae isolates on a pectin-containing medium: A, B and C - with hawthorn containing agar; D- with currant containing agar
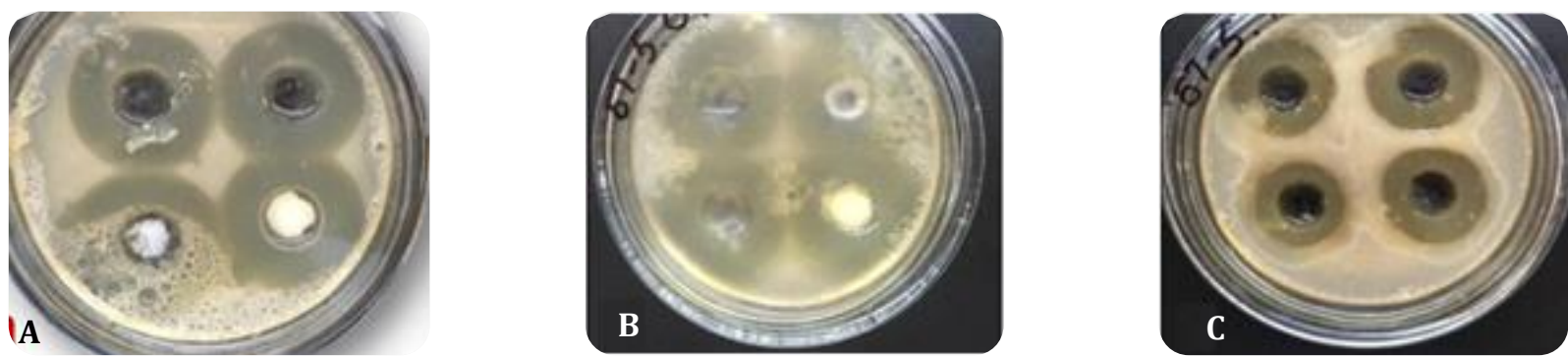

Supplementary Figure 2. The sensitivity of Pseudomonas syringae isolates to antibiotics (A-erythromycin; Bofloxacin; C-penicillin). 

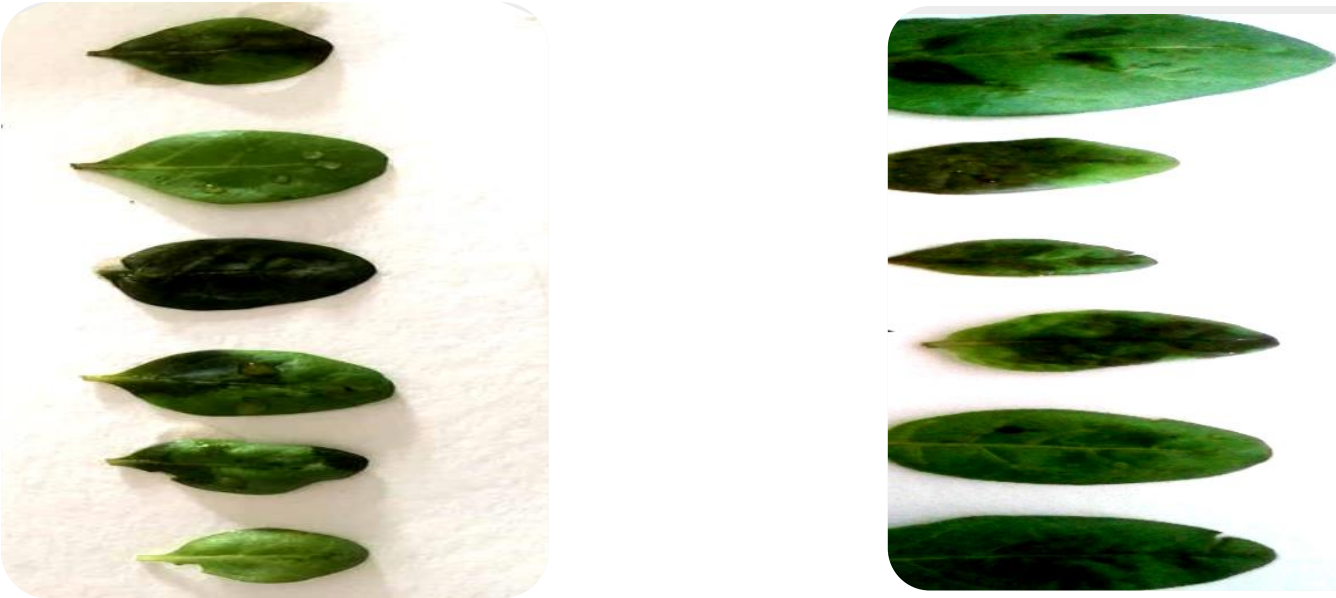

Supplementary Figure 3. Hypersensitivity reaction in tobacco leaves.
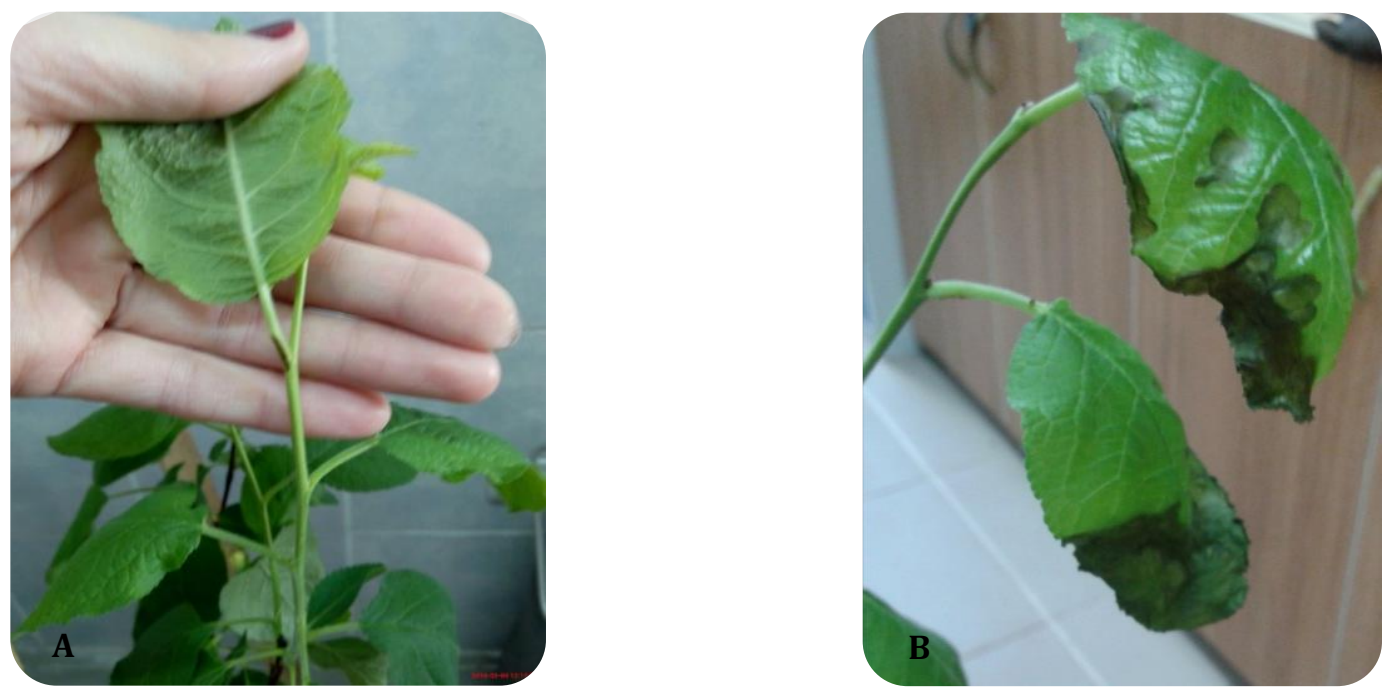

Supplementary Figure 4. A) In 24 hours and B) 5 days after infection apricot seedlings with diseased symptoms on the leaves by spraying with Pseudomonas syringae $\left(1 \times 106 \mathrm{ml}^{-1}\right)$.
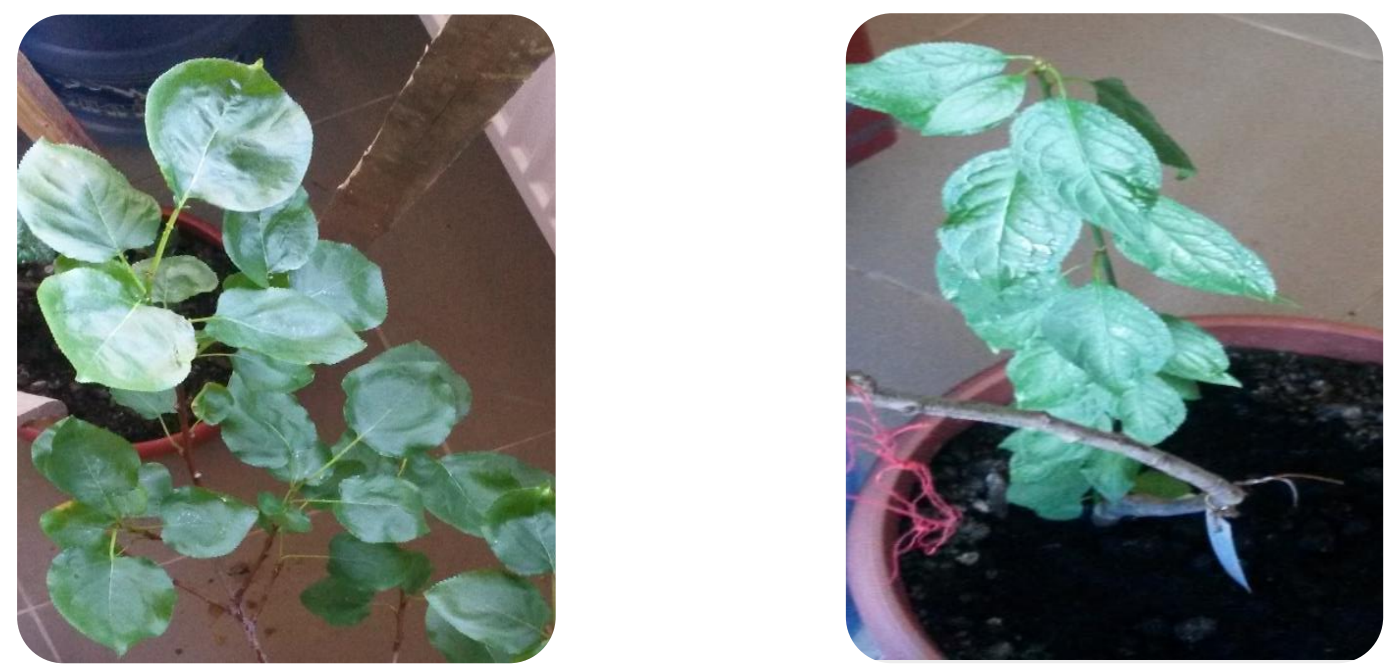

Supplementary Figure 5. Recovering leaves of apricot and black plum seedlings 30 days after second treatment by Streptomyces C1-4 at a dose of $10^{6}$ spores $/ \mathrm{ml}$. 
Supplementary Table 1 . The origin and cultural features of Streptomyces strains used in this study.

\begin{tabular}{|c|c|c|}
\hline Name of strains & Site of isolation & $\begin{array}{l}\text { Cultural characteristics on SAA (starch } \\
\text { ammonium agar) }\end{array}$ \\
\hline Streptomyces fumanus, gn-2 & $\begin{array}{l}\text { From the rhizosphere of mustard } \\
\text { (Sinapis alba), the Issyk-Kul region }\end{array}$ & $\begin{array}{l}\text { It forms velvety aerial mycelium } \\
\text { of a pink-lilac colour and with a specific } \\
\text { odour on SAA }\end{array}$ \\
\hline $\begin{array}{l}\text { Streptomyces } \\
\text { diastochromogenes, Sk-6.6 }\end{array}$ & $\begin{array}{l}\text { From soil of Son-Kul Valley, at an } \\
\text { altitude of } 3200 \mathrm{~m} \text { above sea level }\end{array}$ & $\begin{array}{l}\text { It forms an aerial mycelium with a } \\
\text { white-yellowish colour and a specific } \\
\text { odour on SAA }\end{array}$ \\
\hline Streptomyces sp. C1-4 & $\begin{array}{l}\text { From soil of Son-Kul Valley, at an } \\
\text { altitude of } 3200 \mathrm{~m} \text { above sea level }\end{array}$ & $\begin{array}{l}\text { It forms an aerial mycelium with a light- } \\
\text { green colour and specific odour on SAA }\end{array}$ \\
\hline Streptomyces sp. $\operatorname{Pr}-3$ & $\begin{array}{l}\text { From soil of experimental field of } \\
\text { Agricultural Faculty, KTU Manas }\end{array}$ & $\begin{array}{l}\text { It forms an aerial mycelium with a } \\
\text { lemon-yellow colour, white edge; the } \\
\text { surface is raised on SAA }\end{array}$ \\
\hline Streptomyces sp. KK-4 & $\begin{array}{l}\text { From soil of experimental field of } \\
\text { Agricultural Faculty, KTU Manas }\end{array}$ & $\begin{array}{l}\text { Forms aerial mycelium of a yellow } \\
\text { colour on SAA, substrate mycelium is } \\
\text { dark red. } \\
\text { The colonies form a continuous growth } \\
\text { on the surface of the medium }\end{array}$ \\
\hline Streptomyces sp. K-3.3 & $\begin{array}{l}\text { From soil of experimental field of } \\
\text { Agricultural Faculty, KTU Manas }\end{array}$ & $\begin{array}{l}\text { Forms aerial mycelium of a white colour } \\
\text { on SAA }\end{array}$ \\
\hline Streptomyces sp. ПАТ-3 & $\begin{array}{l}\text { From soil of experimental field of } \\
\text { Agricultural Faculty, KTU Manas }\end{array}$ & $\begin{array}{l}\text { Forms aerial mycelium of a white colour } \\
\text { on SAA, substrate mycelium is pink in } \\
\text { colour }\end{array}$ \\
\hline
\end{tabular}

Publisher's note: EScience Press remains neutral with regard to jurisdictional claims in published maps and institutional affiliations.

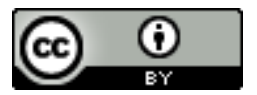

Open Access This article is licensed under a Creative Commons Attribution 4.0 International License, which permits use, sharing, adaptation, distribution and reproduction in any medium or format, as long as you give appropriate credit to the original author(s) and the source, provide a link to the Creative Commons license and indicate if changes were made. The images or other third-party material in this article are included in the article's Creative Commons license, unless indicated otherwise in a credit line to the material. If material is not included in the article's Creative Commons license and your intended use is not permitted by statutory regulation or exceeds the permitted use, you will need to obtain permission directly from the copyright holder. To view a copy of this license, visit http://creativecommons.org/licenses/by/4.0/. 